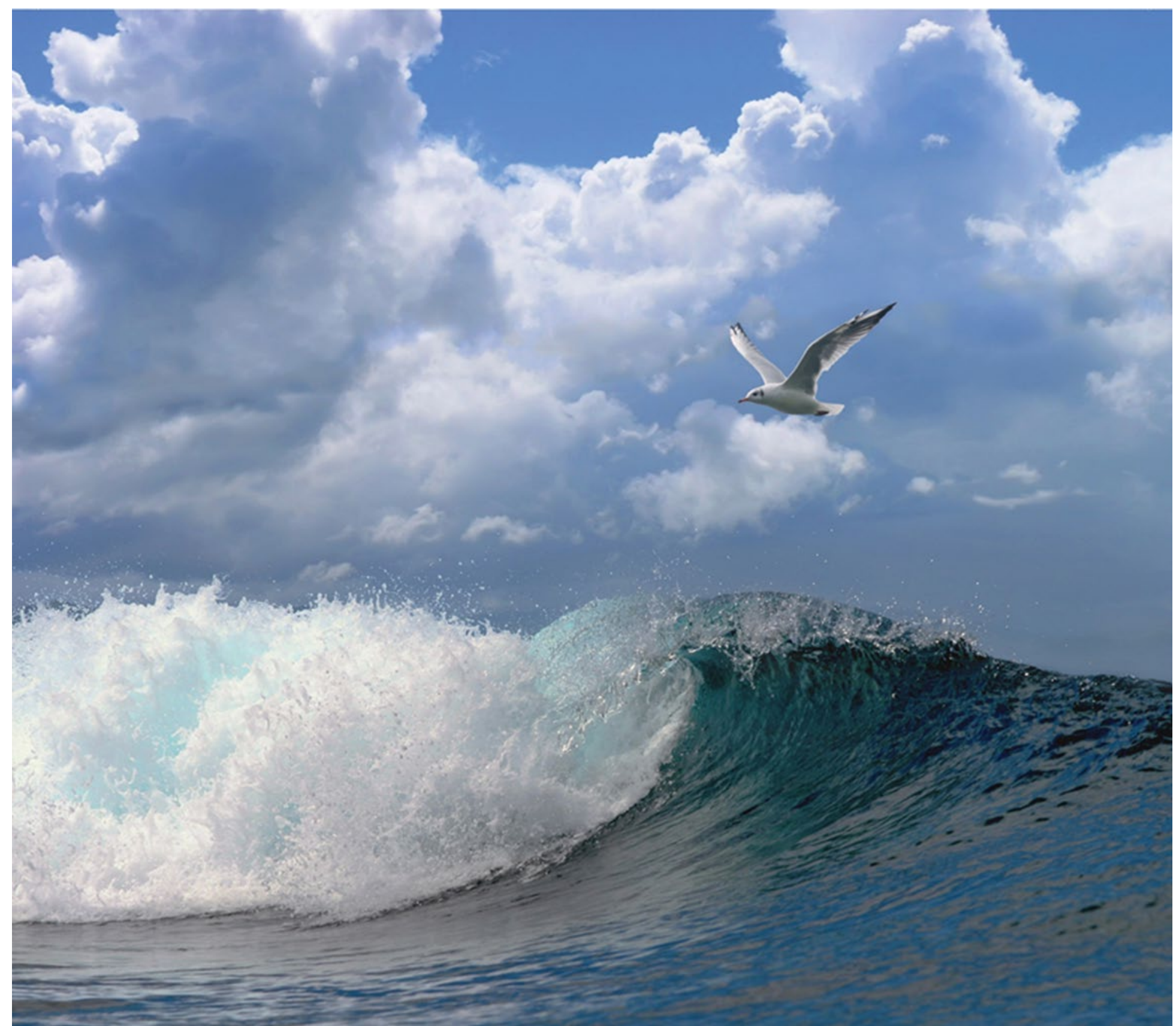

Expert inschatting van nieuwe windparkzoekgebieden op de Noordzee voor verschillende soortgroepen

Auteur(s): R.H. Jongbloed, J.E. Tamis, J. Steenbergen (Eds) 


\section{Expert inschatting van nieuwe windparkzoekgebieden op de Noordzee voor verschillende soortgroepen}

Auteur(s): $\quad$ R.H. Jongbloed, J.E. Tamis, J. Steenbergen (Eds)

Dit onderzoek is uitgevoerd door Wageningen Marine Research en gesubsidieerd door het Ministerie van Landbouw, Natuur en Voedselkwaliteit, in het kader van het Beleidsondersteunend onderzoekthema 'Natuurinclusieve Energie' en project 'Implementatie van het Noordzeeakkoord' (BO-43-023.03-012) 
Opdrachtgever: Ministerie van Landbouw, Natuur en Voedselkwaliteit

T.a.v.: F.S. Tichelaar MSc

Postbus 20401

2500 EK Den Haag

BO-43-023.03-012

Dit rapport is gratis te downloaden van https://doi.org/10.18174/533540

Wageningen Marine Research verstrekt geen gedrukte exemplaren van rapporten.

Wageningen Marine Research is ISO 9001:2015 gecertificeerd.

(C) Wageningen Marine Research

Wageningen Marine Research, instituut binnen de rechtspersoon Stichting

Wageningen Research, hierbij vertegenwoordigd door Dr. M.C.Th. Scholten, Algemeen directeur

KvK nr. 09098104,

WMR BTW nr. NL 8113.83.696.B16.

Code BIC/SWIFT address: RABONL2U

IBAN code: NL 73 RABO 0373599285
Wageningen Marine Research aanvaardt geen aansprakelijkheid voor gevolgschade, noch voor schade welke voortvloeit uit toepassingen van de resultaten van werkzaamheden of andere gegevens verkregen van Wageningen Marine Research. Opdrachtgever vrijwaart Wageningen Marine Research van aanspraken van derden in verband met deze toepassing.

Alle rechten voorbehouden. Niets uit deze uitgave mag weergegeven en/of gepubliceerd worden, gefotokopieerd of op enige andere manier gebruikt worden zonder schriftelijke toestemming van de uitgever of auteur. 


\section{Inhoud}

Samenvatting

$1 \quad$ Inleiding

2 Aanpak

10

3 Synthese kennis en beperkingen op basis van expert inschattingen

3.1 Zeevogels $\quad 12$

3.1.1 Informatie over verspreiding en effecten $\quad 12$

$\begin{array}{lll}3.1 .2 & \text { Risico's windparkzoekgebieden } & 13\end{array}$

$\begin{array}{ll}3.1 .3 & \text { Benodigde extra informatie }\end{array}$

3.1.4 Kennis en onderzoek voor identificeren windparkzoekgebied 15

$\begin{array}{ll}3.1 .5 & \text { Conclusies }\end{array}$

3.2 Zeehonden 16

3.2.1 Informatie over verspreiding en effecten 16

$\begin{array}{ll}3.2 .2 & \text { Risico's windparkzoekgebieden } \\ 3.2 .3 & 18\end{array}$

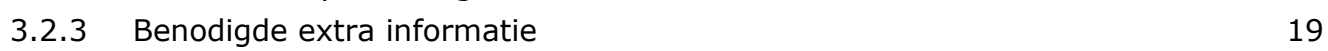

3.2.4 Kennis en onderzoek voor identificeren windparkzoekgebied 19

$\begin{array}{ll}3.2 .5 & \text { Conclusies }\end{array}$

$\begin{array}{lll}3.3 & \text { Bruinvis en andere walvisachtigen } & 20\end{array}$

$\begin{array}{lll}\text { 3.3.1 Informatie over verspreiding en effecten } & 20\end{array}$

$\begin{array}{lll}3.3 .2 & \text { Risico's windparkzoekgebieden } & 22\end{array}$

$\begin{array}{lll}\text { 3.3.3 Benodigde extra informatie } & 23\end{array}$

3.3.4 Kennis en onderzoek voor identificeren windparkzoekgebied 24

$\begin{array}{lll}3.3 .5 & \text { Conclusies } & 24\end{array}$

$\begin{array}{lll}3.4 & \text { Vleermuizen } & 25\end{array}$

3.4.1 Informatie over verspreiding en effecten $\quad 25$

$\begin{array}{lll}3.4 .2 & \text { Risico's windparkzoekgebieden } & 26\end{array}$

$\begin{array}{ll}3.4 .3 & \text { Benodigde extra informatie }\end{array}$

3.4.4 Kennis en onderzoek voor identificeren windparkzoekgebied 27

$\begin{array}{lll}3.4 .5 & \text { Conclusies } & 27\end{array}$

$\begin{array}{lll}3.5 & \text { Vissen } & 28\end{array}$

3.5.1 Informatie over verspreiding en effecten $\quad 28$

$\begin{array}{lll}3.5 .2 & \text { Risico's windparkzoekgebieden } & 29\end{array}$

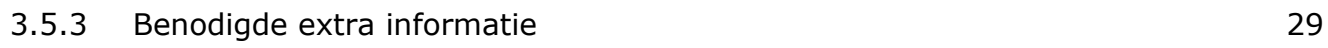

$\begin{array}{lll}3.5 .4 & \text { Conclusies } & 29\end{array}$

$\begin{array}{lll}3.6 & \text { Rifbouwende soorten } & 30\end{array}$

3.6.1 Informatie over verspreiding en effecten 30

3.6.2 Risico's windparkzoekgebieden $\quad 35$

$\begin{array}{lll}3.6 .3 & \text { Benodigde extra informatie } & 35\end{array}$

3.6.4 Conclusies 36

$\begin{array}{lll}3.7 & \text { Risico's van windparkzoekgebieden voor soortgroepen } & 36\end{array}$

$\begin{array}{llr}4 & \text { Algemene conclusies } & 38\end{array}$

$\begin{array}{llr}5 & \text { Kwaliteitsborging } & 40\end{array}$

$\begin{array}{lr}\text { Literatuur } & \mathbf{4 1}\end{array}$

$\begin{array}{lr}\text { Verantwoording } & 44\end{array}$

Bijlage I. Vragen aan experts van WMR over nieuwe windparkzoekgebieden op het NCP 


\section{Samenvatting}

De Nederlandse regering gaat, om haar ambitie voor groene energie door middel van wind op zee te kunnen verwezenlijken, gebieden aanwijzen waarbinnen de ontwikkeling van windparken op termijn mag gaan plaatsvinden; de zoekgebieden. Inzicht in de mogelijke ecologische impact per windparkzoekgebied wordt daarbij betrokken. Kennis, veldgegevens en modellen voor een expliciete ruimtelijke inschatting van impact van windparken op de natuur waren (en zijn), echter, niet voor alle soorten en/of soortgroepen aanwezig of zijn onevenredig beschikbaar. Daarnaast staat de methodologie voor het bepalen van de interacties en cumulatieve effecten in de kinderschoenen. Om toch inzicht te krijgen in de mogelijke impact per windparkzoekgebied is op 4 februari 2020 door Rijkswaterstaat (RWS) een zogenaamde expertworkshop georganiseerd: Gebiedensessie Nieuwe Windgebieden Noordzee. Aanvullend op deze workshop is in juni 2020 een consultatie van Wageningen Marine Research (WMR) experts uitgevoerd, welke in deze notitie wordt beschreven. Verschillende WMR experts hebben op basis van een vragenlijst een inschatting gegeven van de potentiele/meest waarschijnlijke impact op soortgroepen van de te bouwen windparken in acht zoekgebieden. De focus lag met name op verschillen tussen de zoekgebieden en minder op de algemene impact van windparken op soorten.

Op hoofdlijnen kan het volgende geconcludeerd worden m.b.t. gevoeligheid van soortgroepen voor offshore windparken en hun ruimtelijke ligging:

- Er bestaat onvoldoende kennis om kwantificeerbaar geschikte gebieden te kiezen.

- Expert inschattingen worden gedaan op basis van:

- Veelal verspreidingsgegevens.

Beperkingen: o.a. niet altijd up-to-date, niet compleet met betrekking tot gebied en/of periode (snapshots).

- Impact windparken.

Beperkingen: operationele fase minder goed bekend; doorwerking populatieniveau voor de meeste soort(groepen) niet bekend; gedrag binnen/buiten windparken niet (goed) bekend.

- Bestaande lokale kennis

Beperkingen: er is geen zicht op bijvoorbeeld effecten van cumulatie in ruimte maar vooral ook in de tijd.

- Respons afhankelijk van de soort:

- Zeevogels en vissen betreffen relatief diverse gemeenschappen met veel soorten;

- Zeevogels: windpark gevoeligheidskaart (geïntegreerd over soorten en ruimtelijk) beschikbaar en bruikbaar, zij het enigszins verouderd en aan vernieuwing toe; er zijn nieuwe verspreidingsgegevens beschikbaar voor alle soorten zeevogels, voor het hele NCP. Daarbij is er ook nieuwe informatie beschikbaar over de gevoeligheid van de diverse soorten zeevogels.

- Vissen: zeer diverse groep, valt weg bij aggregatie waardoor de inschatting neutraal wordt voor alle gebieden.

- Trekvogels ontbreken in huidige inschatting. In de workshop viel deze groep onder de expertise van Bureau Waardenburg.

- Biogene riffen:

- Kansen ingeschat op basis van verspreidingskaarten rifbouwende soorten.

- Mogelijke impact op benthos in het algemeen ontbreekt: effecten door verandering bodemsamenstelling (op bodemleven en ecosysteem) en aangroei palen (door toename filtratie fytoplankton).

Voor wat betreft de verschillen tussen de zoekgebieden blijkt dat het risico voor:

- Zeevogels sterk varieert per gebied (laag, neutraal, hoog).

- De minste effecten worden verwacht voor de zoekgebieden 1, 2, 6 en 8;

- De meeste effecten worden verwacht voor de zoekgebieden 3, 5 en 7. 
- Zeehonden weinig verschilt tussen de zoekgebieden;

- Voor alle zoekgebieden zijn de potentiele effecten op de grijze zeehond groot.

- Voor zoekgebieden 3, 6 en 7 zijn de potentiele effecten op de gewone zeehond onduidelijk. Voor de overige gebieden zijn de potentiele effecten groot.

- Bruinvis en andere walvisachtigen sterk varieert per gebied (laag, hoog, onduidelijk);

- de minste effecten worden verwacht voor zoekgebied 1;

- de meeste effecten worden verwacht voor de zoekgebieden 2, 3 ,4 en 8

- voor de zoekgebieden 5, 6 en 7 zijn de potentiele effecten onduidelijk.

- Vleermuizen slechts voor twee zoekgebieden ingeschat kan worden (voor zoekgebieden 1 en 2 is het risico hoog), andere gebieden zijn onduidelijk;

- Vissen voor alle gebieden neutraal is ingeschat vanwege de zeer grote diversiteit van de soortgroep;

- Rifbouwende soorten bestaat uit kansen die zijn ingeschat op basis van potentiele vestiging van rifbouwende soorten.

- Zoekgebied 4 biedt de meeste kans (potentieel geschikt voor alle (4) beschouwde rifbouwende soorten).

- Zoekgebied 7 biedt de minste kans (potentieel geschikt voor 1 rifbouwende soort, de gewone mossel), gevolgd door zoekgebied 6 (potentieel geschikt voor 2 rifbouwende soorten).

- De overige zoekgebieden 1, 2, 3, 5 en 8 bieden kans voor 3 rifbouwende soorten.

- Aan de hand van de expert schattingen voor alle soortgroepen tezamen, inclusief kansen voor rifbouwende soorten, is de rangorde op volgorde van afnemende geschiktheid als volgt:

- Zoekgebied 1;

- Zoekgebied 2 en 8;

- Zoekgebied 4 en 6;

- Zoekgebied 5 en 7;

- Zoekgebied 3. 


\section{$1 \quad$ Inleiding}

De Noordzee is het leefgebied van veel verschillende diersoorten; vogels (zowel zeevogels als trekvogels), zeezoogdieren (o.a. zeehonden en bruinvis), vissen en invertebraten. Dit is echter ook het gebied waar de regering haar ambitie voor groene energie door middel van wind op zee heeft gepland. Om deze ambitie te kunnen verwezenlijken, worden er gebieden aangewezen waarbinnen de ontwikkeling van windparken op termijn mag gaan plaatsvinden, de zoekgebieden.

Om te komen tot een afgewogen keuze voor nieuwe zoekgebieden voor de realisatie van windparken wordt idealiter rekening gehouden met de verwachte (lokale) impact van de te bouwen windparken op de verschillende soorten en soortgroepen. De Rijksoverheid heeft in verschillende fases windenergiegebieden gereserveerd, die in het Nationaal Waterplan worden aangewezen: Borssele en IJmuiden Ver (2009); Hollandse Kust en Ten noorden van de Waddeneilanden (2014); uitbreiding Hollandse Kust (zuid) en Hollandse Kust (noord) (2016). De vaststelling van een nationaal waterplan verloopt via de procedure van een rijksstructuurvisie. In de procedure weegt het kabinet alle belangen af, dus ook die van bijvoorbeeld visserij, scheepvaart en natuur, waarbij onder andere een milieueffectrapportage (plan-MER) wordt opgesteld (https://windopzee.nl/onderwerpen-0/windzee/landingspagina-0/totstandkoming/). Op grond van de Wet windenergie op zee, die op 1 juli 2015 in werking is getreden, is een toets van de natuuraspecten onderdeel van het kavelbesluit ${ }^{1}$. Naast het kavelbesluit is er voor bouwen en exploiteren van een windpark geen aparte ontheffing of vergunning op grond van de Wet natuurbescherming meer nodig, omdat deze afweging al in het kavelbesluit is gedaan en opgenomen. Kennis, veldgegevens en modellen voor een expliciete ruimtelijke inschatting van impact van windparken op de natuur waren (en zijn), echter, niet voor alle soorten en/of soortgroepen aanwezig of zijn onevenredig beschikbaar. Daarnaast staat de methodologie voor het bepalen van de interacties en cumulatieve effecten in de kinderschoenen.

Om toch inzicht te krijgen in de mogelijke impact per windparkzoekgebied is op 4 februari 2020 door Rijkswaterstaat (RWS) een zogenaamde expertworkshop georganiseerd: Gebiedensessie Nieuwe Windgebieden Noordzee. Aanvullend op deze workshop is in juni 2020 een consultatie van Wageningen Marine Research (WMR) experts uitgevoerd, welke in deze notitie wordt beschreven. De consulatie heeft gediend als input voor de kentallen-analyse in relatie tot het Programma Noordzee 2022-2027 (Roebeling et al., in voorbereiding). De meeste geconsulteerde WMR experts waren aanwezig bij de workshop. Zowel de expertworkshop als deze (aanvullende) consultatie hadden als doel om, daar waar mogelijk, op basis van expertbeoordeling per soortgroep de waarde van (acht vooraf gestelde) zoekgebieden op de Noordzee te duiden. Bij de expertworkshop waren de zoekgebieden nog niet beschikbaar, daar is gekeken welke gebieden op het NCP meer of minder geschikt waren voor de uitrol van windenergie op zee. De ligging, oppervlakte en potentiele capaciteit van deze acht zoekgebieden is weergegeven in Figuur 1 en Tabel 1 en zijn gebaseerd op de kennis die in juni 2020 voor handen was. Het resultaat van deze consultatie zal worden meegenomen in het lopende proces voor het opstellen van het Programma Noordzee 2022-2027 door de overheid.

\footnotetext{
${ }^{1}$ Kavelbesluit is een besluit waarin een kavel (locatie voor een windpark) en een tracé voor een aansluitverbinding zijn aangewezen (Artikel 1, Wet windenergie op zee: https://wetten.overheid.nl/BWBR0036752/2020-01-01).
} 


\section{Tabel 1 Windparkzoekgebieden}

Zoekgebied $\mathrm{nr}$. Locatie zoekgebied

Oppervlakte Capaciteit

$(\mathrm{km} 2)$

(GW)

\begin{tabular}{|c|c|c|c|}
\hline 1 & Op de grens met Norfolk Boreas & 900 & 9 \\
\hline 2 & Ten noorden van IJmuiden-ver & 1000 & 10 \\
\hline 3 & $\begin{array}{l}\text { Ten noordwest van IJmuiden ver, tussen de twee } \\
\text { scheepvaartroutes in }\end{array}$ & 300 & 3 \\
\hline 4 & Defensie oefengebied ten noorden van de Wadden & 1300 & 13 \\
\hline 6 & $\begin{array}{l}\text { Gebied ten noorden van Friese Front, ten westen van nieuwe } \\
\text { scheepvaart passage }\end{array}$ & 2000 & 20 \\
\hline 7 & Ten oosten van Klaverbank & 1000 & 10 \\
\hline
\end{tabular}




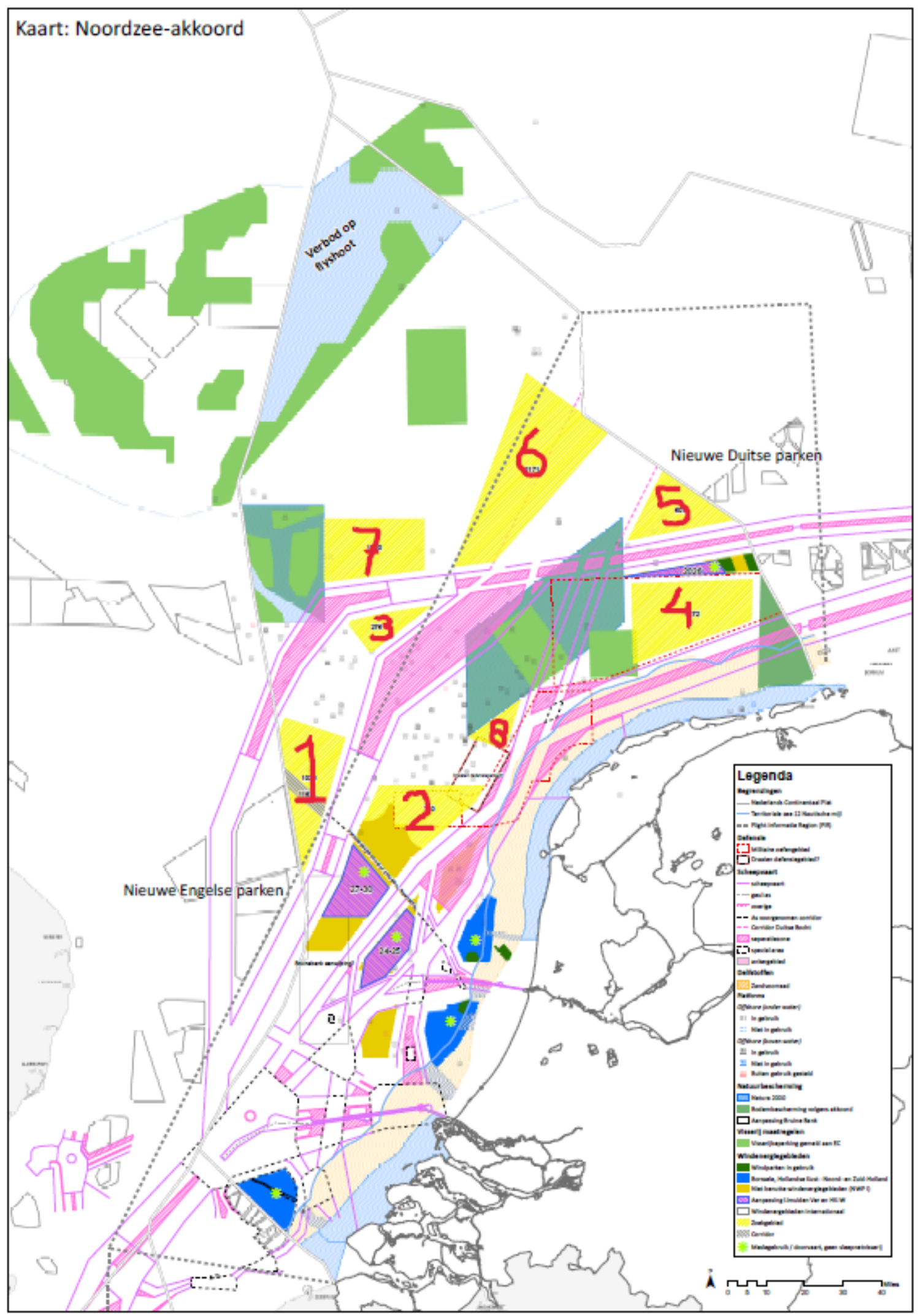

Figuur 1 Kaart met nieuwe windparkzoekgebieden op het Nederlandse deel van de Noordzee. NB. De weergave van deze kaart is beperkt. Dit is echter de best mogelijke weergave aangezien alleen deze (werk) versie beschikbaar is. 


\section{Aanpak}

Verschillende WMR experts (Tabel 2) hebben op basis van een vragenlijst (zie bijlage 1) een inschatting gegeven van de potentiele/meest waarschijnlijke impact van de te bouwen windparken in de acht zoekgebieden. De focus lag met name op verschillen tussen de zoekgebieden en minder op de algemene impact van windparken op soorten. Onderstaande notitie geeft een overzicht van de resultaten.

Tabel 2 WMR experts met hun expertisegebied en aanwezigheid bij de Gebiedensessie Nieuwe Windgebieden Noordzee op 4 februari 2020

WMR-experts
\begin{tabular}{|l|l|l|}
\hline Mardik Leopold & Zeevogels* & Ja \\
\hline Sophie Brasseur & Zeehonden & Ja \\
\hline $\begin{array}{l}\text { Steve Geelhoed en } \\
\text { Meike Scheidat }\end{array}$ & $\begin{array}{l}\text { Bruinvis en andere } \\
\text { walvisachtigen }\end{array}$ & ja (S. Geelhoed), nee (M. Scheidat) \\
\hline Sander Lagerveld & Vleermuizen & Nee\# \\
\hline Ralf van Hal & Vissen & Nee \\
\hline Oscar Bos & $\begin{array}{l}\text { Benthos m.n. rifbouwende } \\
\text { soorten }\end{array}$ & la \\
\hline
\end{tabular}

* De groep trekvogels is niet opgenomen in deze exercitie, terwijl deze wel onderdeel was van de expertworkshop Gebiedensessie Nieuwe Windgebieden Noordzee op 4 februari 2020. De reden is dat de betrokken experts voor trekvogels afkomstig zijn van Bureau Waardenburg.

\# Maarten Platteeuw (RWS) heeft input geleverd voor de sessie, mede op basis van inbreng van S. Lagerveld (WMR).

De experts zijn onder andere gevraagd een inschatting te maken over welke windparkzoekgebieden meer of minder effecten zullen hebben op de desbetreffende soortgroep en daarbij ook aan te geven met welke zekerheid die inschatting te maken is. Hierbij is gebruik gemaakt van categorieën (Tabel 3). Bij elke inschatting is een indicatie van de zekerheid gegeven: Laag (L); Medium / matig (M); Redelijk / relatief hoog $(R)$; niet ingeschat of niet relevant (-).

In hoofdstuk 3 zijn per soortgroep de geschatte risico's van zoekgebieden voor windparken weergegeven (paragraaf 3.1 tot en met 3.6) en in paragraaf 3.7 zijn de risico's samengevoegd tot één overzicht. Daarbij moet worden opgemerkt dat dit een inschatting is van één (of twee) experts per soortgroep (zie Tabel 2), op basis van kennis en ervaring, waarbij geen gericht onderzoek aan vooraf is gegaan.

Tabel 3 Categorieën (on)geschiktheid en bijbehorend risico van zoekgebieden voor windparken

\begin{tabular}{|l|l|l|}
\hline Categorie & Risico & Omschrijving \\
\hline 1) Meer geschikt & Laag & Verwachte negatieve effecten zijn minimaal \\
\hline 2) Minder geschikt & Hoog & Negatieve effecten verwacht \\
\hline 3) Neutraal & Medium & Geen bijzonderheden (gebied is niet van specifiek belang) \\
\hline $\begin{array}{l}\text { 4) Windpark is kans voor } \\
\text { soort/soortgroep }\end{array}$ & Kans & Positieve effecten verwacht \\
\hline 5) Onduidelijk (te weinig kennis) & Onbekend & Onvoldoende kennis \\
\hline
\end{tabular}

\section{Disclaimer}

De hier gepresenteerde overzichten zijn het resultaat van een beknopte consultatie, waarbij geen uitputtend literatuuronderzoek of nieuw veldonderzoek heeft plaatsgevonden.

De consultatie heeft zich, vanwege de korte doorlooptijd die nodig was voor de toepassing van het resultaat in het lopende proces voor het opstellen van het Programma Noordzee 2022-2027 door de overheid, beperkt tot een expert per soort(groep), met uitzondering van de bruinvis en andere 
walvisachtigen. Het is mogelijk dat er meer of andere informatie uit deze consultatie was gekomen wanneer er meerdere experts per soort(groep) waren betrokken. Ook is de consultatie beperkt tot de zes vragen uit de vragenlijst. 


\section{Synthese kennis en beperkingen op basis van expert inschattingen}

In dit hoofdstuk is op basis van de antwoorden van de experts (zie Bijlage I voor de gestelde vragen) per soortgroep het volgende weergegeven:

1. een overzicht van beschikbare kennis en beperkingen met betrekking tot:

a. de verspreiding van de soortgroep;

b. mogelijke effecten van windparken.

2. een inschatting van risico's van de acht zoekgebieden op basis van de huidige kennis, inclusief de zekerheid hierover.

3. een overzicht van extra kennis en informatie nodig voor een goede/betrouwbare inschatting.

4. suggesties voor het identificeren van zoekgebieden voor windparken op zee.

Tot slot (paragraaf 3.7) zijn de risico's van de 8 zoekgebieden voor alle soortgroepen in een overzicht weergegeven.

\section{$3.1 \quad$ Zeevogels}

Op basis van de input van Mardik Leopold.

\subsubsection{Informatie over verspreiding en effecten}

Hieronder is aangegeven welke informatie is gebruikt voor de totstandkoming van de kaarten van de Gebiedensessie Nieuwe Windgebieden Noordzee gehouden op 4 februari 2020 en/of de aanvullende consultatie en wat de beperkingen zijn van die informatie, zoals aangegeven door de expert.

Zeevogels vormen, taxonomisch gezien, een diverse groep soorten. Het betreft alle vogels die zijn aangepast aan een leven of zee, waar ze gedurende het hele jaar, of gedurende een deel van het jaar leven, en waar ze hun voedsel vinden.

Relatieve geschiktheid van gebieden voor ontwikkeling van offshore wind, ten opzichte van zeevogels is gebaseerd op de WMR windmolengevoeligheidskaart voor alle zeevogels samen (Leopold et al., 2014). De beperkingen van de gebruikte gegevens zijn:

- Gebaseerd op oude informatie. Er is voor vijf vogelsoorten afzonderlijk een update geweest (van der Wal et al., 2018; van Kooten et al., 2019) maar de windmolengevoeligheidskaart voor alle zeevogels samen is (nog) niet ge-update.

- Op de windmolengevoeligheidskaarten zijn nieuwere verspreidingsgegevens, zoals de sterns in de noordelijke hoek nog niet opgenomen.

- Niet specifiek voor de nieuwe zoekgebieden;

- $\quad$ Er is weinig bekend over de veranderlijkheid van verspreidingspatronen op zee, en zeker niet op het niveau van zoekgebieden.

- Het is een gemiddelde over meerdere vogelsoorten samen, en geeft een goed beeld van geschikte en minder geschikte gebieden, maar zegt niets over eventuele juridische houdbaarheid en effecten op de Staat van Instandhouding van specifieke beschermde soorten. 
Informatie over de effecten is gebaseerd op de WMR windmolengevoeligheidskaart voor alle zeevogels samen (Leopold et al., 2014), zie Figuur 2. De beperkingen daarvan zijn:

- $\quad \mathrm{Er}$ is de laatste jaren meer specifieke informatie over gevoeligheid van enkele zeevogelsoorten voor windparken door botsingen en habitatverlies bekend geworden (o.a. in WOZEP: van der Wal et al., 2018; van Kooten et al., 2019). Dat is niet in de WMR windmolengevoeligheidskaart voor zeevogels van Leopold et al. (2014) opgenomen. Er is daarom een update van de kaart nodig, waarin deze informatie is meegenomen, evenals nieuwe data over verspreiding van de verschillende soorten zeevogels.

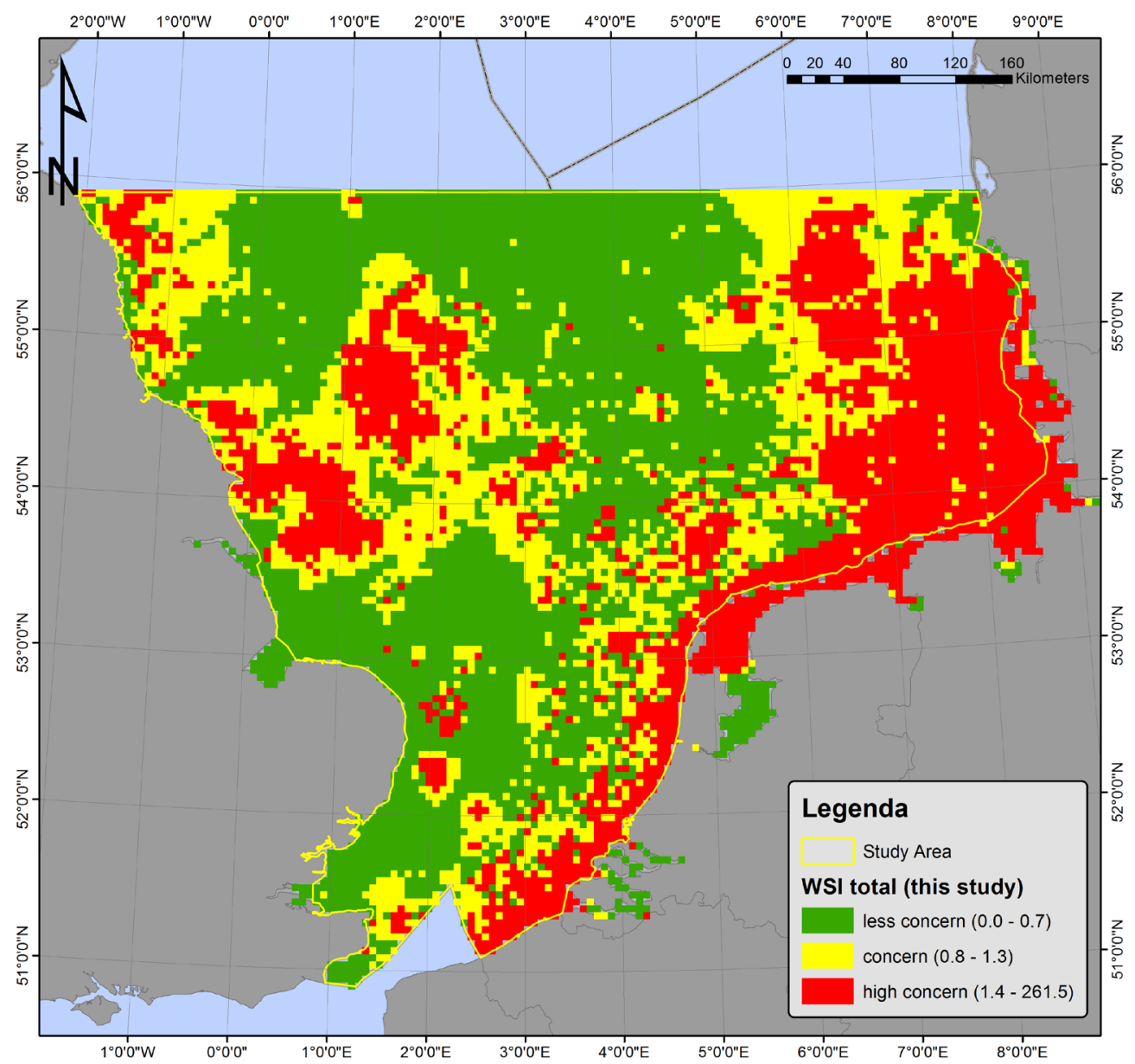

Figuur 2 Windmolengevoeligheidskaart voor zeevogels op de Noordzee (Leopold et al., 2014).

\subsubsection{Risico's windparkzoekgebieden}

De expert is gevraagd een inschatting te maken over welke windparkzoekgebieden meer of minder geschikt zijn voor wind op zee ten aanzien van de desbetreffende soortgroep en daarbij ook aan te geven met welke zekerheid die inschatting te maken is.

De geschatte risico's van de windparkzoekgebieden voor zeevogels zijn hieronder aangegeven, waarbij de volgende classificering is gebruikt: Laag (negatieve effecten zijn naar verwachting minimaal); Hoog (verwachte negatieve effecten); Neutraal (geen bijzonderheden / gebied is niet van specifiek belang); Onduidelijk (onvoldoende kennis om (on)geschiktheid in te schatten). Bij elke inschatting is een indicatie van de zekerheid gegeven. 
- $\quad$ Risico windparkzoekgebied 1 Laag (matige zekerheid)

Fors gebied ten zuidwesten van Friese Front (FF) in drukke omgeving. Vraag is wel in hoeverre dit gebied een refugium is voor die drukke omgeving. Dat is onbekend.

- $\quad$ Risico windparkzoekgebied 2 Laag (matige zekerheid)

Fors gebied ten zuiden van FF in drukke omgeving. Vraag is hier ook in hoeverre dit gebied een refugium is voor die drukke omgeving. Dat is onbekend.

- $\quad$ Risico windparkzoekgebied 3 Hoog (redelijke zekerheid)

Klein gebied in aanvoerroute FF. Te verwachten zijn hoge dichtheden alken en zeekoeten.

Bovendien broeden er drieteenmeeuwen op de gasplatforms en dit zal toenemen na decommissioning als de platforms blijven staan.

- $\quad$ Risico windparkzoekgebied $4 \quad$ Neutraal (lage zekerheid)

Relatief onbekend gebied qua zeevogels. Ligt in verlengde van FF dus er zal doorstroming zijn van alken en zeekoeten. Maar het ligt relatief zuidelijk t.o.v. FF dus wellicht gaan de meesten alken en zeekoeten er noord bij langs. Dit is echter niet goed onderzocht. Het ligt binnen bereik van de kleine mantelmeeuwen van de Waddeneilanden.

- $\quad$ Risico windparkzoekgebied $5 \quad$ Hoog (lage zekerheid)

Relatief onbekend gebied qua zeevogels. Ligt precies in verlengde van FF dus er zal doorstroming zijn van alken en zeekoeten. Dit is echter niet goed onderzocht. In combinatie met gebied 4 en Gemini ontstaat hier een forse blokkade van de doorstroming vanuit FF naar Duitse Bocht en door naar Kattegat/Skagerrak, waar veel van de FF zeekoeten vermoedelijk naar op weg zijn. Gebied ligt vrijwel buiten bereik van de kleine mantelmeeuwen van de Waddeneilanden

- $\quad$ Risico windparkzoekgebied $6 \quad$ Laag (matige zekerheid)

Fors gebied, in de Oestergronden. Dit is op zich een vogelrijk gebied, maar tevens valt het binnen een groot en relatief uniform gebied voor wat betreft de zeevogels. Een windpark claimt daarvan dan een deel. De vraag die hier speelt is hoeveel gebied er over blijft voor de zeevogels en of dit genoeg is voor de integriteit van de populatie(s). Daar is geen kennis over. Vanwege de ligging, ver uit de kust, is er geen interactie met broedvogels.

- $\quad$ Risico windparkzoekgebied $7 \quad$ Hoog (lage zekerheid)

Ligt dichter bij de rijke Klaverbank dan gebied 6 en lijkt daarom (qua zeevogels)

kwetsbaarder dan gebied 6 . Verder vergelijkbare problematiek als gebied 6.

- Risico windparkzoekgebied 8 Laag (redelijke zekerheid). Klein, relatief vogelarm gebied ten zuiden van het Friese Front. Wel nog binnen bereik van broedvogels (kleine mantelmeeuwen) van de westelijke Waddeneilanden, met name Texel en Vlieland.

\subsubsection{Benodigde extra informatie}

Volgens de expert inschatting zou de volgende (type) informatie nodig zijn om een inschatting van de risico's in de toekomst goed te kunnen maken:

- Gebruik windparken door zeevogels (gedrag individuen en soorten) en/of toename dichtheden zeevogels buiten de parken

Vooral de gebieden ten noorden van het Friese Front zijn relatief slecht onderzocht. De problematiek is hier wel relatief simpel: het gaat vooral om pelagische vogelsoorten (alk, zeekoet, jan van gent, drieteenmeeuw, noordse stormvogel, maar ook echt slecht bekende want slecht zichtbare- soorten als kleine alk en papegaaiduiker). Gebieden die grenzen aan reeds drukke gebieden: windparken en scheepvaartroutes, zullen daarmee een interactie vertonen. Vogels die een scheepvaartroute mijden, zullen ook een nieuw windpark mijden. De kwestie is dan: blijft er genoeg "leeg" gebied over? Onderzocht zou moeten worden in hoeverre de dichtheden zeevogels oplopen in de overgebleven lege gebieden en in hoeverre ze toch windparken gaan/blijven gebruiken. Voor zover bekend is er geen lopend of gepland onderzoek op dit gebied.

- Bewegingen van zeevogels over de Noordzee met GPS trackers De bewegingen van zeevogels over de Noordzee, in de loop van het jaar, is erg slecht bekend dus we weten niet goed waar eventuele bottlenecks zitten. Bij hele grote aaneengesloten windmolenparken op zee zouden er blokkades kunnen ontstaan. We zullen moeten nagaan hoe belangrijk corridors zijn. Onderzoek met GPS trackers zou bijdragen aan de nodige 
kennis. Voor een aantal soorten is hiervoor samenwerking nodig met buitenlandse onderzoekers, in het Verenigd Koninkrijk en Duitsland.

\subsubsection{Kennis en onderzoek voor identificeren windparkzoekgebied}

Met betrekking tot zeevogels zijn de volgende suggesties gegeven voor het identificeren van zoekgebieden voor windparken op zee:

- Vermijden van gebieden die belangrijk zijn voor zeekoeten en alken met hun jongen in de zomer. Door gebieden ter hoogte van, en ten noorden van, het Friese Front zwemmen in de zomer zeekoeten en alken met hun jongen, op weg naar het Friese Front en verder. Dit speelt niet, of in ieder geval veel minder, ten zuiden van het Friese Font. Wel is het gebied rond de Bruine Bank in de winter belangrijk voor beide soorten. Overal op zee zitten in de winter zeevogels, maar de meest kwetsbare (vogels die zich vooral zwemmend verplaatsen, en broedvogels die vanuit kolonies opereren), worden het minst verstoord ten zuiden van het Friese Front (zeekoeten en alken) en verder uit de kust (broedvogels).

- Uitbreiding van windparken aansluiten bij bestaande windparken, met onderzoek met GPStrackers van bewegingen van zeevogels en mogelijke blokkades door hele grote aaneengesloten industriegebieden op zee. Liefst zoveel mogelijk aansluiten bij reeds bestaande parken. Er komt wel een nieuw probleem om de hoek kijken bij verdere uitbouw, namelijk dat er blokkades aan het ontstaan zijn bij hele grote aaneengesloten industriegebieden op zee. We zullen moeten nagaan hoe belangrijk corridors zijn. Maar we kennen de bewegingen van zeevogels over de Noordzee, in de loop van het jaar, nog maar erg slecht dus we weten ook niet goed waar eventuele bottlenecks zitten. Onderzoek met GPS trackers lijkt hiervoor erg belangrijk. De volgende generatie windparken op zee wordt ook veel groter dan de parken van de huidige generatie waar veel onderzoek is gedaan. De effecten van de komende schaalvergroting zijn onbekend en onderzoek aan bestaande, veel kleinere parken geeft hierin ook weinig inzicht.

- Gedrag van zeevogels binnen de parken. We weten niet in hoeverre zeevogels (en wélke zeevogels: individuen en soorten) zullen leren om te gaan met windparken op de Noordzee. Als ze dat kunnen, is het probleem wellicht kleiner dan nu gedacht. Daarom is het zinnig om naar gedrag van vogels binnen de parken te gaan kijken, met inachtneming van de schaal van de windparken.

\subsubsection{Conclusies}

In het algemeen kan op basis van de expert inschattingen het volgende geconcludeerd worden:

- Er bestaat onvoldoende kennis om kwantificeerbaar geschikte gebieden aan te wijzen.

- Expert inschattingen worden gedaan op basis van verspreidingsgegevens

- Beperkingen: o.a. verspreiding is niet up-to-date, niet compleet met betrekking tot gebied en/of periode (snapshots).

Voor zeevogels kan op basis van de expert inschattingen het volgende geconcludeerd worden:

- Zeevogels betreft een gemeenschap bestaande uit veel soorten en respons verschilt per soort.

- Zeevogel-windpark gevoeligheidskaart (geïntegreerd over soorten en ruimtelijk) beschikbaar en bruikbaar, maar inmiddels wel enigszins verouderd en niet compleet.

- Beperkingen van de huidige kennis:

- doorwerking populatieniveau niet bekend;

- gedrag binnen/buiten windparken niet bekend.

- $\quad$ De minste effecten worden verwacht voor de zoekgebieden 1, 2, 6 en 8 .

- De meeste effecten worden verwacht voor de zoekgebieden 3, 5 en 7. 


\subsection{Zeehonden}

Op basis van input van Sophie Brasseur

\subsubsection{Informatie over verspreiding en effecten}

Hieronder is aangegeven welke informatie is gebruikt voor de totstandkoming van de kaarten van de Gebiedensessie Nieuwe Windgebieden Noordzee gehouden op 4 februari 2020 en/of de aanvullende consultatie en wat de beperkingen zijn van die informatie, zoals aangegeven door de expert.

- Er zijn geen gedetailleerde kaarten of coördinaten beschikbaar gesteld. Inschatting van de effecten zijn daarom op zicht gemaakt en zijn er geen berekeningen uitgevoerd.

Verspreiding van zeehonden op zee is gebaseerd op de volgende gegevens:

- Zenderdata is verzameld in het kader van diverse onderzoeken (Figuur 3). Ten bate van detail onderzoek op specifieke locaties zijn zeehonden gezenderd vanuit verschillende locaties en verschillende seizoenen; in totaal 564 dieren (tussen 1997 en 2018), waarbij meer dan 250 gewone en bijna 100 grijze zeehonden met gedetailleerde GPS zenders. Ondanks deze hoge aantallen, zijn er zowel ruimtelijk als temporeel beperkingen van deze gegevens. Daarnaast is er rekening gehouden met bestaande zenderdata uit het Verenigd Koninkrijk. Hiervoor gelden dezelfde beperkingen als voor de Nederlandse data.
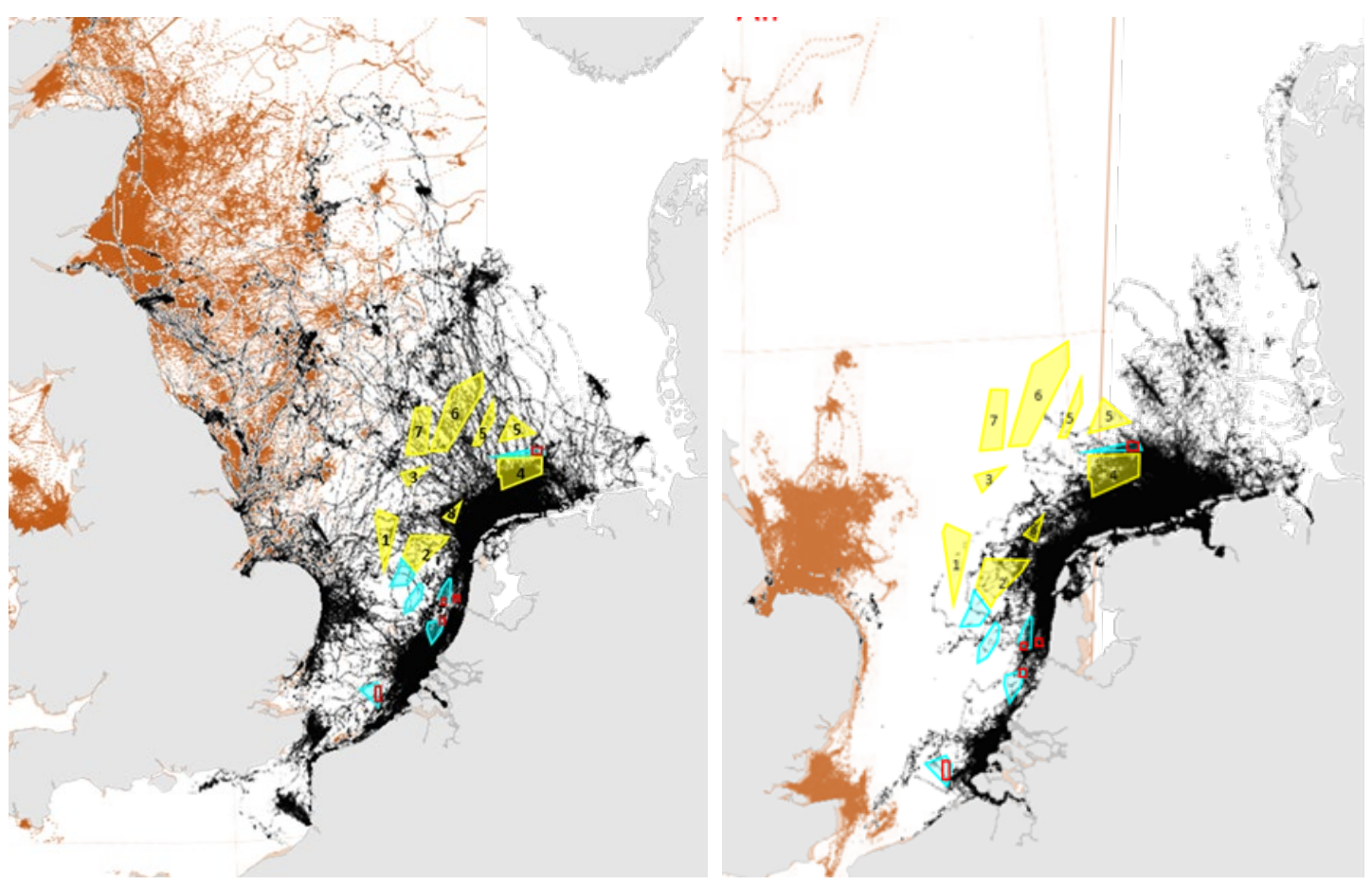

Figuur 3 Compilatie van zenderdata van grijze zeehonden (links) en gewone zeehonden (rechts) verzameld tussen 1991 en 2018. De zenderdata uit de UK is gekopieerd (Russel et al. 2017) en in het rood aan de Nederlandse data toegevoegd. Gele, blauwe en rode vlakken geven een impressie van de locaties van respectievelijk de nieuwe zoekgebieden, de bestaande zoekgebieden en de bestaande windparken op het NCP. 
- Zenderdata en populatie tellingen op land vormen de basis voor verspreidingsmodellen van zeehonden op zee (o.a. Aarts et al. 2016). Hiermee wordt een voorspelling gemaakt van de dichtheden van de gewone en grijze zeehonden op zee. De twee soorten vertonen sterke verschillen, die te maken hebben met de historie (grijze zeehonden hebben pas rond 1985 Nederland gekoloniseerd), grootte en seizoen patroon (grijze zeehonden planten zich voort in de winter, gewone zeehonden in de zomer).

Voor de gewone zeehonden is er een verspreidingsmodel gemaakt voor de verschillende maanden van het jaar. Sturende factoren in de modellen zijn daarnaast de verspreiding op land, de bathymetrie en bodemsoort (Aarts et al. 2016). Bij gebrek aan financiering is in deze modellen geen rekening gehouden met menselijke activiteit en is geen vergelijkbaar model opgesteld voor de grijze zeehonden. Verwacht wordt dat in 2021 voor de gewone zeehond een nieuw model beschikbaar komt waar factoren van menselijke activiteiten zoals vaaractiviteiten, seismisch onderzoek en windparken in het model worden meegenomen.

- De bewegingen gemeten aan individuele dieren alleen, zijn niet representatief voor de soort. Overlap met de geplande gebieden geeft echter wel aan dat er dieren kunnen voorkomen in het gebied.

Informatie over de effecten is gebaseerd op het volgende:

- Gedrag bij het aanleggen van windparken:

Een groot deel van de zeehonden werden gezenderd in het kader van de aanleg van de windparken in Nederland (OWEZ, Gemini, Luchterduinen en Borssele). Er zijn sterke aanwijzingen dat de zeehonden zich al op vele tientallen kilometers gewaar zijn van de bouwactiviteiten en vaak hun gedrag hierop aanpassen (Aarts et al., 2018;). Afhankelijk van het seizoen zijn de dieren afhankelijk van verschillende factoren zoals voedsel (op zee), maar ook bijvoorbeeld de mogelijkheid te migreren naar voorplantingsgebied.

- Vermijding of gebruik van operationele windparken.

Uitgaande van de zenderdata voor beide soorten blijkt dat zeehonden in het algemeen operationele windparken mijden, op enkele uitzonderingen (individuen) na (Russell et al., 2014). Onderzoek naar de verstoring door windparken ontbreekt. Hierbij zou men bijvoorbeeld kunnen achterhalen tot op welke afstand een operationele park effect heeft, en hoe omgevingsvariabelen dit zou beïnvloeden, en hoe de dieren functioneren bij de aanwezigheid van meerdere parken. Zenderonderzoek in het kader van de bouw van Borssele (WOZEP, 2019-2021) voor zowel grijze als gewone zeehonden is een kans om effecten van een nabijgelegen park te toetsen en een koppeling te maken met de aantallen op de kant.

- Aantalsontwikkeling van beide soorten Jaarlijks worden tellingen van gewone en grijze zeehonden internationaal gecoördineerd (Cremer et al., 2019; Galatius et al., 2019; ICES 2020). De aantalsontwikkeling van de grijze zeehonden in Nederland is voor een groot deel afhankelijk van de ontwikkelingen in het VK, waar een veel grotere populatie is en is daarom moeilijk te interpreteren (https://www.wur.nl/nl/show/Populatie-Grijze-Zeehonden-in-de-NederlandseWaddenzee.htm). Bij de gewone zeehond is de ontwikkeling veel meer lokaal (internationale Waddenzee, deltagebied) gestuurd. Bij deze soort wordt in de afgelopen 10 jaar een trendbreuk in de populatiegroei geconstateerd (https://www.wur.nl/nl/show/PopulatieGewone-Zeehonden-in-de-Nederlandse-Waddenzee.htm).

- Ruimte/foerageermogelijkheden van andere (m.n. concurrerende) soorten (zeezoogdieren, vogels, vissen).

Bij gebrek aan kennis over zowel de beschikbare prooi (vis) in tijd en ruimte, als de andere (m.n. concurrerende), is het niet mogelijk de benodigde ruimte/foerageermogelijkheden van in te schatten (Aarts et al., 2019). Verschuiving van deze soorten naar de minder verstoorde gebieden zal immers effect hebben op de zeehonden. 


\subsubsection{Risico's windparkzoekgebieden}

De expert is gevraagd een inschatting te maken over welke windparkzoekgebieden meer of minder geschikt zijn voor wind op zee ten aanzien van de desbetreffende soortgroep en daarbij ook aan te geven met welke zekerheid die inschatting te maken is.

De geschatte risico's van de windparkzoekgebieden voor zeehonden zijn hieronder aangegeven, waarbij de volgende classificering is gebruikt: Laag (negatieve effecten zijn naar verwachting minimaal); Hoog (verwachte negatieve effecten); Neutraal (geen bijzonderheden / gebied is niet van specifiek belang); Onduidelijk (onvoldoende kennis om (on)geschiktheid in te schatten). Bij elke inschatting is een indicatie van de zekerheid gegeven. De expert heeft aangegeven dat de inschatting is gemaakt binnen de huidige range van verspreiding.

- $\quad$ Risico windparkzoekgebied 1

- $\quad$ Risico windparkzoekgebied 2

- $\quad$ Risico windparkzoekgebied 3

- $\quad$ Risico windparkzoekgebied 4

- $\quad$ Risico windparkzoekgebied 5

- $\quad$ Risico windparkzoekgebied 6

- $\quad$ Risico windparkzoekgebied 7

- $\quad$ Risico windparkzoekgebied 8
Gewone zeehond: Hoog (redelijke zekerheid); Grijze zeehond: Hoog (redelijke zekerheid)

Gewone zeehond Hoog (redelijke zekerheid); Grijze zeehond: Hoog (redelijke zekerheid)

Gewone zeehond: Onduidelijk

Grijze zeehond: Hoog (redelijke zekerheid)

Gewone zeehond: Hoog (redelijke zekerheid);

Grijze zeehond: Hoog (redelijke zekerheid)

Gewone zeehond: Hoog (redelijke zekerheid);

Grijze zeehond: Hoog (redelijke zekerheid)

Gewone zeehond: Onduidelijk;

Grijze zeehond: Hoog (redelijke zekerheid)

Gewone zeehond: Onduidelijk;

Grijze zeehond: Hoog (redelijke zekerheid)

Gewone zeehond: Hoog (redelijke zekerheid);

Grijze zeehond: Hoog (redelijke zekerheid)

Uit het bovenstaande blijkt dat voor elk zoekgebied negatieve effecten worden verwacht (risico hoog). Deze risico's zijn vervolgens in meer detail ingeschat op basis van het belang van de gebieden voor de beide zeehondensoorten, op basis van overlap met zenderdata (huidig gebruik); potentieel foerageergebied; en potentieel migratiegebied (Tabel 4). Er wordt voor beide soorten verwacht dat er effecten zullen zijn in de gebieden 1, 2, 4, 5 en 8 en voor de grijze zeehond ook in gebied 3, 6 en 7. Vooralsnog is het onduidelijk hoe belangrijk deze 3 gebieden zijn voor de gewone zeehonden, als migratie gebied tussen het VK en NL of als potentieel foerageergebied, wanneer de voorgenomen menselijke activiteiten de dieren verder uit de kust drijven.

Tabel 4 Risico's van de windparkzoekgebieden voor zeehonden op basis van expert inschatting (pv: gewone zeehond; hg: grijze zeehond). Scores: 0: geen belang; 1: belang onduidelijk; 2: belang; 3: groot belang.

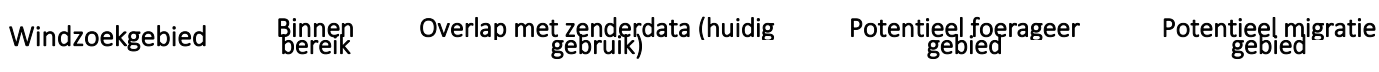

\begin{tabular}{|c|c|c|c|c|c|c|c|c|}
\hline & $\mathrm{pv}$ & $\mathrm{hg}$ & $\mathrm{pv}$ & $\mathrm{hg}$ & $\mathrm{pv}$ & $\mathrm{hg}$ & $\mathrm{pv}$ & $\mathrm{hg}$ \\
\hline $\mathbf{1}$ & 2 & 3 & 2 & 2 & 1 & 2 & 2 & 3 \\
\hline $\mathbf{2}$ & 3 & 3 & 3 & 2 & 3 & 2 & 3 & 3 \\
\hline $\mathbf{3}$ & 1 & 3 & 0 & 2 & $1^{*}$ & 2 & $1^{*}$ & 3 \\
\hline $\mathbf{4}$ & 3 & 3 & 3 & 3 & 3 & 3 & 3 & 3 \\
\hline $\mathbf{5}$ & 2 & 3 & 2 & 2 & 2 & 2 & $1^{*}$ & 3 \\
\hline $\mathbf{6}$ & 1 & 3 & 0 & 2 & $1^{*}$ & 2 & $1^{*}$ & 3 \\
\hline $\mathbf{7}$ & 1 & 3 & 0 & 2 & $1^{*}$ & 2 & $1^{*}$ & 3 \\
\hline $\mathbf{8}$ & 3 & 3 & 3 & 3 & 3 & 3 & 3 & 3 \\
\hline
\end{tabular}

*op basis van genetische data is duidelijk dat er uitwisseling is tussen UK en NL, er is vooralsnog niet extra onderzocht of hier potentieel geschikte foerageermogelijkheden zijn. 


\subsubsection{Benodigde extra informatie}

Volgens de expert inschatting zou de volgende (type) informatie nodig zijn om een inschatting van de risico's in de toekomst goed te kunnen maken:

- Afhankelijkheid van zeehonden voor specifieke gebieden en effecten van verandering omstandigheden

Afhankelijkheid en plasticiteit van individuele dieren voor wat betreft hun voorkeur voor specifieke gebieden en de mogelijkheid alternatieve gebieden te bezoeken (bijvoorbeeld: hoe ver uit van de ligplaatsen kunnen zeehonden gaan, voordat dit hun overleving beïnvloed; (hoe snel) kunnen ze switchen?). Er wordt momenteel al gewerkt aan een individual based model (IBM) waarmee een eerste beeld verkregen kan worden van de effecten van veranderende omstandigheden op de energetische balans van zeehonden (NWO onderzoek). Door ontwikkeling van accelerometrie in zenders, ten behoeve van meer gedetailleerde gedragsonderzoek (TKI) met betere zenders, kan wellicht beter worden geregistreerd waar dieren eten en hoe dieren op verstoringen reageren.

- Populatie-effecten van verstoring Effect (van verstoring) op populatie - hoe beïnvloeden (verstoring door) windparken de overleving/ voortplanting van zeehonden. Is bijvoorbeeld de huidige afname van de populatie gewone zeehonden in de Waddenzee een gevolg van de bestaande parken (inclusief Deense, Duitse, Belgische en Engelse parken) en/of de toename van activiteit eromheen? Wat is het mechanisme? Ruimte tekort, onderbreking van foerageren? (Mislukte) emigratie?

- Voedselbeschikbaarheid en -competitie

Beschikbaar voedsel voor zeehonden en effect van competitie met andere predatoren? Op dit ogenblik is relatief weinig bekend over het werkelijke beschikbare voedsel (vis) voor zeehonden. Met name de grove temporele en ruimtelijke schaal wordt gemonitord en het gebrek aan kennis over de selectiviteit van de gebruikte netten speelt hier een rol. Er loopt momenteel onderzoek (seals \& sandeels (NIOZ-NWO)) waar gekeken wordt naar bentische vissen en de ruimtelijke en temporele variatie hierin in de omgeving van gebieden waar zeehonden veel zijn gevolgd.

- Langjarig beeld van gebiedsgebruik zeehonden Kennis over jaar op jaar veranderingen in gebiedsgebruik door zeehonden. Tot nu toe zijn vooral kort op verschillende (door de projecten bepaalde) plekken dieren gevolgd. Het ontbreekt aan een langjarig beeld van hoe de zeehonden kunnen variëren in het gebruik van hun gebied. En hoe leeftijd/ geslacht hierin een rol speelt. Met name de verschuivingen lange termijn als gevolg van veranderingen in menselijk gebruik zijn cruciaal wanneer er op zo'n grote schaal het gebied wordt veranderd. Hiervoor zou ideaal gezien specifiek meerjarig/seizoen zenderdata voor beide soorten gegenereerd moeten worden, eventueel aangevuld met bestaande gegevens. Men zou bijvoorbeeld in het Eemsgebied waar tussen 2009 en 2011 veelvuldig is gezenderd, opnieuw moeten zenderen om de effecten van de explosieve toename van wind op zee (m.n. in Duitsland) waar te nemen. De verkregen resultaten (bezoek/ ontwijking van windparken; veranderd foerageer gedrag/ afstand tot ligplaatsen; veranderde duur op ligplaatsen) kunnen als model dienen voor de nog te plannen parken en wellicht helpen bij het verklaren van de huidige afname van de gewone zeehonden populatie.

\subsubsection{Kennis en onderzoek voor identificeren windparkzoekgebied}

Met betrekking tot zeehonden zijn de volgende suggesties gegeven voor het identificeren van zoekgebieden voor windparken op zee:

- $\quad \mathrm{Er}$ is onvoldoende kennis beschikbaar om een kwantificeerbaar systeem (rekening houdend met langjarige processen) te ontwikkelen om geschikte windparkgebieden aan te wijzen. $\mathrm{Er}$ is onvoldoende kennis beschikbaar om een verstandige keuze te maken over een locatie voor windparken op zee. Dit ondanks het feit dat zeehonden wellicht tot de soorten behoren waarvan men relatief het meeste weet (volledig, nauwkeurig, inzicht in (fluctuatie van de) populatie en relatief veel zenderwerk). 


\subsubsection{Conclusies}

Voor zeehonden kan op basis van de expert inschattingen het volgende geconcludeerd worden:

- $\quad$ Er zijn aanwijzingen dat de zeehonden met de huidige menselijke activiteiten beperkt zijn in hun populatie ontwikkeling, het mechanisme is echter nog onduidelijk.

- Beperkingen van de huidige kennis:

- effecten in operationele fase minder goed bekend;

- er is nog geen zicht op het effect van opeenhoping van verschillende menselijke activiteiten (toerisme, aquacultuur, visserij, mijnen, transport, constructie, opwarming) en natuurlijke factoren in het leefgebied van zeehonden.

- doorwerking populatieniveau niet bekend;

- gedrag binnen/buiten windparken niet bekend.

- Voor alle zoekgebieden zijn de potentiele effecten op de grijze zeehond groot.

- Voor zoekgebieden 3, 6 en 7 zijn de potentiele effecten op de gewone zeehond onduidelijk. Voor de overige gebieden zijn de potentiele effecten groot.

\subsection{Bruinvis en andere walvisachtigen}

Op basis van input van Steve Geelhoed en Meike Scheidat

\subsubsection{Informatie over verspreiding en effecten}

Hieronder is aangegeven welke informatie is gebruikt voor de totstandkoming van de kaarten van de Gebiedensessie Nieuwe Windgebieden Noordzee gehouden op 4 februari 2020 en/of de aanvullende consultatie en wat de beperkingen zijn van die informatie, zoals aangegeven door de expert.

Verspreiding van bruinvis en andere walvisachtigen is gebaseerd op de volgende gegevens, inclusief beperkingen daarvan:

- Design-based aantallen en verspreiding a.d.h.v. gestandaardiseerde vliegtuigtellingen in de Nederlandse Noordzee (Geelhoed et al., 2013; Geelhoed \& Scheidat, 2018)

Beperkingen daarvan zijn met name temporeel: Vliegtuigtellingen zijn snapshot in de tijd (in 2010-2011 voorjaar, zomer en najaar, daarna in voorjaar en sinds 2014 in zomer). Actuele informatie over verspreiding door het jaar heen ontbreekt nagenoeg. MWTL-tellingen voorzien deels in deze kennisbehoefte, maar geven minimumverspreiding (want primair gericht op vogels en niet gecorrigeerd voor gemiste dieren).

- Habitat-model based aantallen en verspreiding a.d.h.v. internationale data verzameld tijdens gestandaardiseerde vliegtuigtellingen in de Noordzee (Gilles et al., 2016), zie Figuur 2 t/m Figuur 4

Naast de boven genoemde vliegtuigtellingen op het NCP hebben Gilles et al. (2016) ook gebruik gemaakt van andere vliegtuigtellingen in de Noordzee, waaronder de grensoverschrijdende SCANS-tellingen (Hammond et al., 2013). 


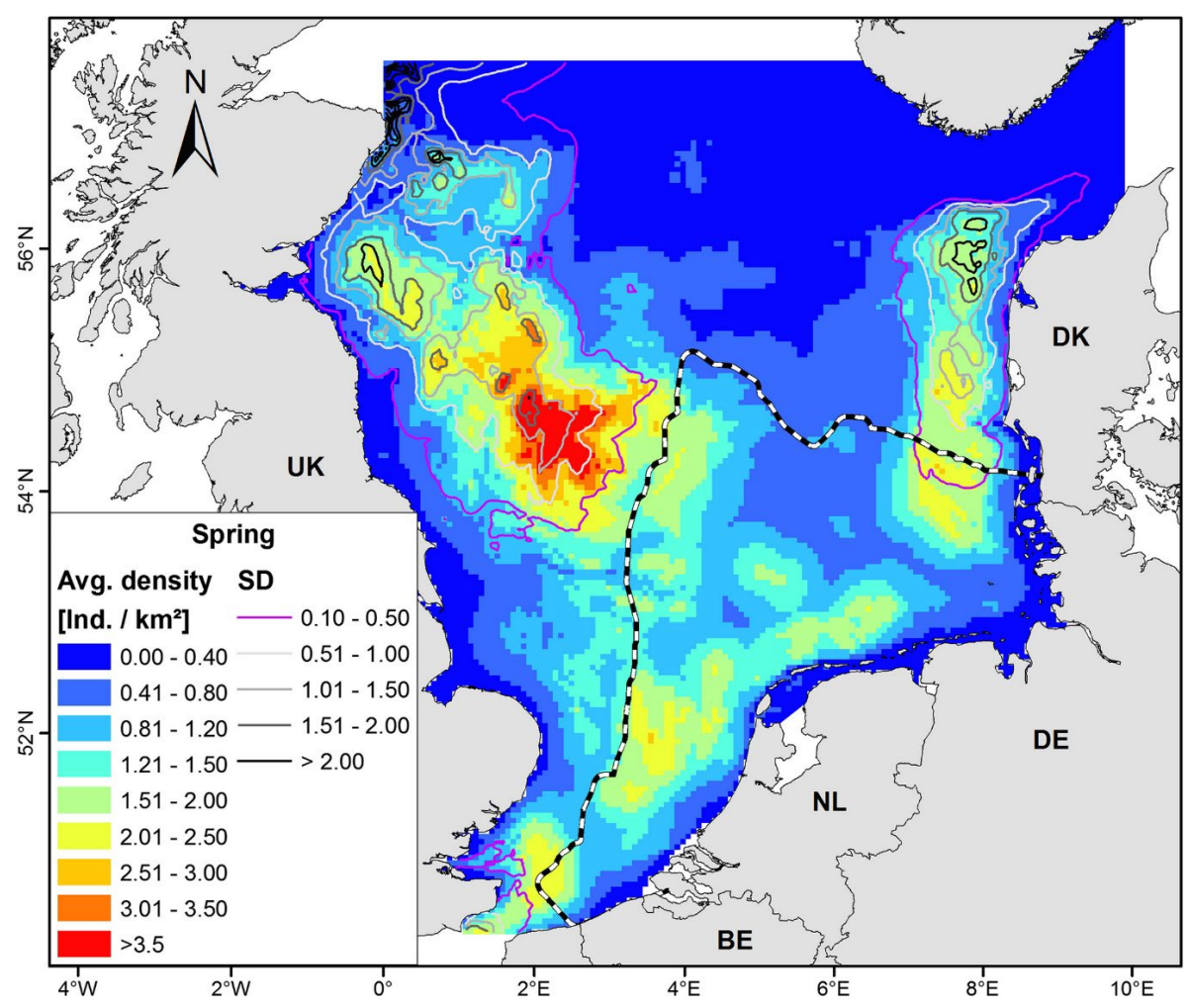

Figuur 4 Gemodelleerde bruinvisverspreiding in de Noordzee in het voorjaar (mrt-mei). De contouren geven de standaarddeviatie (SD) van de dichtheid aan, terwijl de zwart-witte lijn het getelde gebied weergeeft. Bron: Gilles et al. (2016).

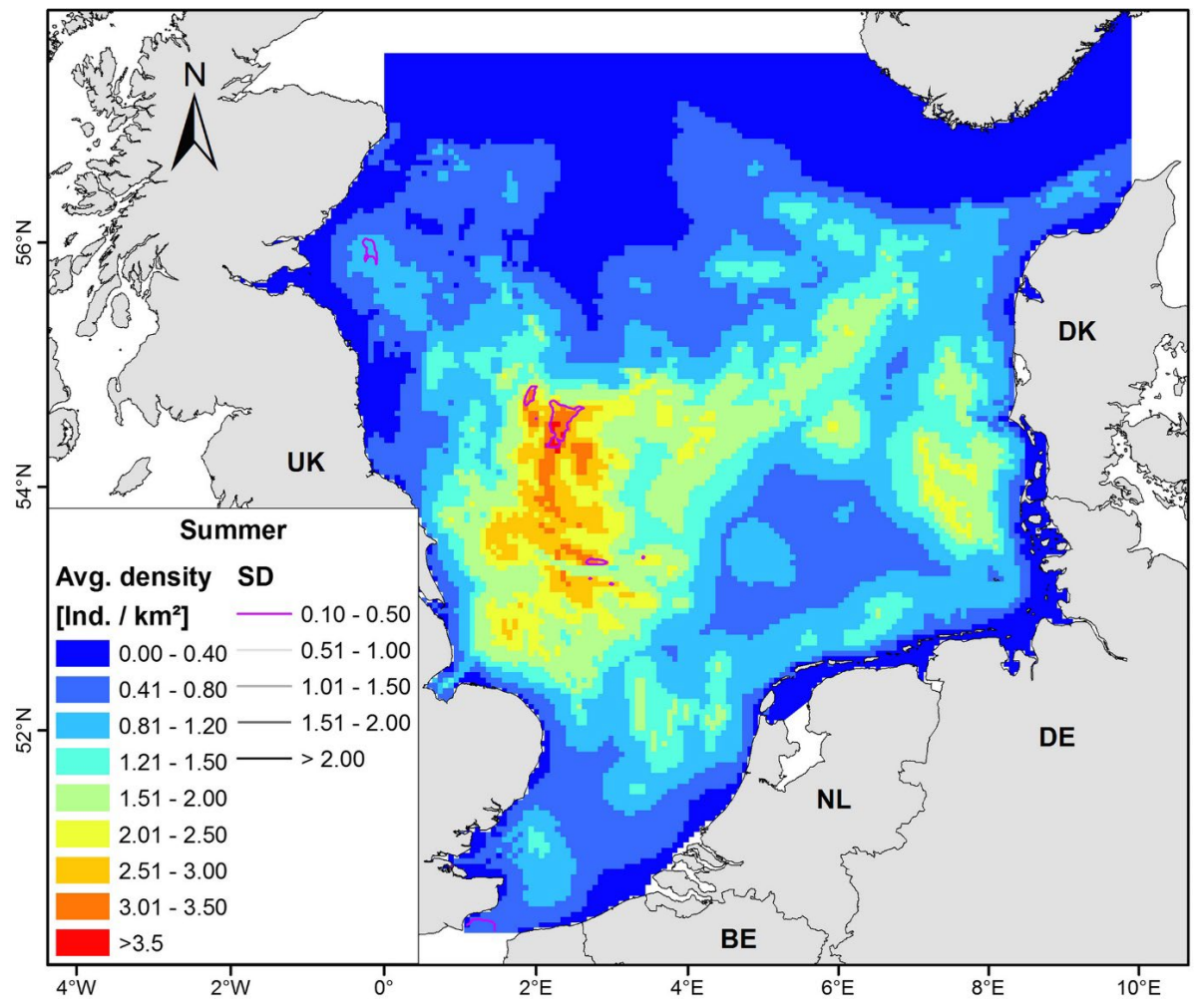

Figuur 5 Gemodelleerde bruinvisverspreiding in de Noordzee in het voorjaar (jun-aug). De contouren geven de standaarddeviatie (SD) van de dichtheid aan. Het gemodelleerde gebied is geheel geteld. Bron: Gilles et al. (2016). 


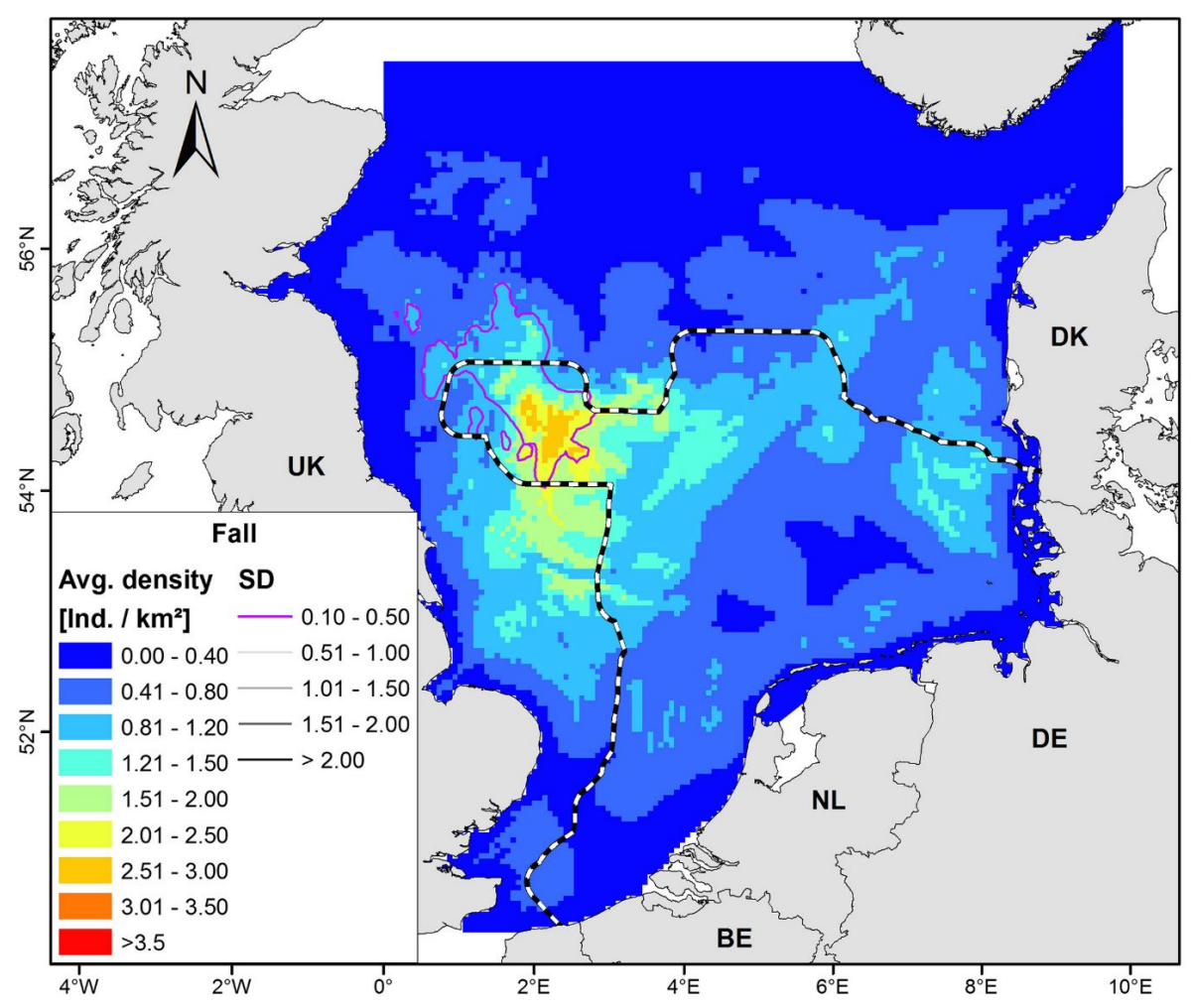

Figuur 6 Gemodelleerde bruinvisverspreiding in de Noordzee in het voorjaar (sep-nov). De contouren geven de standaarddeviatie (SD) van de dichtheid aan, terwijl de zwart-witte lijn het getelde gebied weergeeft. Bron: Gilles et al. (2016).

Informatie over de effecten is gebaseerd op het volgende, inclusief beperkingen daarvan:

- Vermijding of gebruik van windparken tijdens bouw-(Brandt et al., 2016) en productiefase (ICES 2010; Scheidat et al., 2011).

Kennis over gevoeligheid is vrijwel beperkt tot bouwfase. Kennis over vermijding of gebruik van windparken tijdens de operationele fase is versnipperd. Of dichtheden gelijk zijn als voor aanleg parken is onbekend.

- Bruinvissen zijn mobiele dieren en kunnen hun verspreiding zo nodig aanpassen. Momenteel wordt ervan uitgegaan dat voedselbeschikbaarheid de bepalende factor voor bruinvis distributie is (e.g. Rojano-Doñate et al., 2018). Het is aan te nemen dat gebieden met hoge productiviteit, en dus waarschijnlijk veel prooi, waarschijnlijk ook belangrijk voor bruinvissen zijn. Het is niet bekend of foerageermogelijkheden voor bruinvissen in windparken anders zijn: sommige studies suggereren een hogere prooidichtheid door een hogere productiviteit door de structuur van de windparken (rif-effect).

- Andere soorten walvisachtigen: de uitbreiding van de zoekgebieden naar het noorden en westen overlapt met verspreiding van dwergvinvis en witsnuitdolfijn met mogelijke effecten daarvan. Potentiele effecten van windparken op dwergvinvis en witsnuitdolfijn zijn onbekend.

\subsubsection{Risico's windparkzoekgebieden}

De experts zijn gevraagd een inschatting te maken over welke windparkzoekgebieden meer of minder geschikt zijn voor wind op zee ten aanzien van de desbetreffende soortgroep en daarbij ook aan te geven met welke zekerheid die inschatting te maken is.

De invloed van operationele windparken op walvisachtigen is op het moment niet duidelijk. De risico inschatting is gebaseerd op risico's tijdens de bouwfase. De risico's worden ook door de aantallen van windturbines per gebied, de grootte van de palen en ook de manier van bouwen beïnvloed. Voor deze lijst is ervan uitgegaan dat iedere windpark dezelfde soort windturbines heeft en dat de grootte van de zoekgebieden niet proportioneel is met de geplande aantallen van windmolens.

De risico inschatting is gemaakt op basis van overlap van de verspreiding van bruinvissen en zoekgebieden. De kwalificatie moet gezien worden als relatief, uitgaand van vergelijkbaar effect 
tijdens de bouw ongeacht locatie (diepte, sediment) en de huidige verspreiding van bruinvissen. Zoals aangegeven is de verspreiding een snapshot in de tijd en voornamelijk gebaseerd op zomergegevens.

De geschatte risico's van de windparkzoekgebieden voor bruinvis en andere walvisachtigen zijn hieronder aangegeven, waarbij de volgende classificering is gebruikt: Laag (negatieve effecten zijn naar verwachting minimaal); Hoog (verwachte negatieve effecten); Neutraal (geen bijzonderheden / gebied is niet van specifiek belang); Onduidelijk (onvoldoende kennis om (on)geschiktheid in te schatten). Bij elke inschatting is een indicatie van de zekerheid gegeven

- $\quad$ Risico windparkzoekgebied 1 Laag (matige zekerheid) Het gebied ligt ten noorden van de Bruine Bank. De dichtheid van dieren in gebied 1 is relatief laag.

- $\quad$ Risico windparkzoekgebied 2 Hoog (matige zekerheid) Bruinvissen komen hier het hele jaar voor met hoge dichtheden in bepaalde seizoenen.

- $\quad$ Risico windparkzoekgebied 3 Hoog (matige zekerheid) Bruinvissen komen hier het hele jaar voor met hoge dichtheden in bepaalde seizoenen.

- $\quad$ Risico windparkzoekgebied 4 Hoog (matige zekerheid) Het gebied ligt bij de Borkumse Stenen, dat in bepaalde seizoenen hoge dichtheiden herbergt, zowel aan de Nederlandse als de Duitse kant.

- $\quad$ Risico windparkzoekgebied 5 Onduidelijk (matige zekerheid) Risico is onduidelijk i.v.m. grote variatie in dichtheden.

- Risico windparkzoekgebied 6 Onduidelijk (matige zekerheid) Risico is onduidelijk i.v.m. grote variatie in dichtheden.

- $\quad$ Risico windparkzoekgebied 7 Onduidelijk (matige zekerheid) Risico is onduidelijk i.v.m. grote variatie in dichtheden.

- Risico windparkzoekgebied 8 Hoog (matige zekerheid) Bruinvissen komen hier het hele jaar voor met hoge dichtheid tijdens bepaalde seizoenen.

\subsubsection{Benodigde extra informatie}

Volgens de expert inschatting zou de volgende (type) informatie nodig zijn om een inschatting van de risico's in de toekomst goed te kunnen maken:

- Actueel overzicht van aantallen en verspreiding van bruinvissen in meerdere seizoenen Huidige informatie geeft slechts een snapshot in de tijd. Actuele informatie over verspreiding door het jaar heen ontbreekt nagenoeg. In plaats van jaarlijks in voorjaar of zomer worden vliegtuigtellingen in de toekomst twee-/driejaarlijks uitgevoerd, maar dan in voorjaar en zomer. Tellingen in andere seizoenen zijn niet gepland. Deze tellingen zijn gericht om aantallen te berekenen voor het NCP.

- Gebruik van windparken:

- Hoe verhoudt het voorkomen van bruinvissen in een windpark zich tot situatie zonder windpark (heeft windpark een aantoonbaar kwantitatief effect?) en hoe verandert het voorkomen naarmate een windpark langer staat?

- Foerageren bruinvissen in het windpark meer dan buiten het windpark en is dit gerelateerd aan het visvoorkomen (heeft windpark een kwalitatief effect?)

- Om het gebruik door bruinvissen rond windparken in vergelijking met de rest van de NCP te kunnen kwantificeren zou ruimtelijke modellering van de op het moment beschikbare data een zinvol aanzet zijn. Dit is op grotere schaal voor de Noordzee gebeurd voor de situatie tot 2015 (Gilles et al., 2016; voorjaar, zomer en najaar), maar een update is nodig met nieuwe gegevens. Recentelijk is een update uitgevoerd voor de zomerverspreiding t/m 2019 (gegevens zijn nog niet gepubliceerd maar wel gebruikt in von Benda-Beckmann et al. (2020)). Voor overige seizoenen zijn er geen nieuwe data.

- Extra benodigde kennis is het vaststellen van gedetailleerde verspreiding in de windparken, vooral om de palen. Gekoppeld aan veranderingen van het voorkomen van potentiele prooi (binnen vs. buiten windpark en rondom palen vs. tussen palen).

- $\quad$ Er is voor zover publiek bekend geen onderzoek gaande of gepland. Van groot belang voor dergelijk onderzoek zou zijn dat het over een langere periode gebeurt. 
Bijvoorbeeld dat monitoring van het gebruik van het gebied binnen en rondom een windpark/de windmolens door bruinvissen begint zodra een park in de operationele fase is. En dan over een aantal jaren doorgaan om veranderingen in het systeem te kunnen bepalen. Benjamins et al. (2017) hebben onderzoek aan kleinschalig habitat gebruik van bruinvissen rond tidal energy devices gedaan. Een vergelijkbare onderzoeksopzet zou ook voor windmolens toepasbaar zijn, en kan uitgebreid worden met onderzoek aan foerageergedrag.

- Kennis hoe grootschalige veranderingen in de Noordzee het verspreidingspatroon beïnvloeden Mogelijk grote veranderingen in prooi door "regime shift" kan het onmogelijk maken om kleinere verspreidingspatronen te herkennen. Bestaande menselijke activiteiten kunnen de verspreidingspatronen beïnvloeden (bijvoorbeeld scheepsvaart).

- Modellering van de gegevens uit de recent geupdate database van alle systematisch (line-transect distance sampling) doorgevoerde vliegtuigtellingen rekening houdend met verschillende parameters, zoals proxies voor prooi en menselijke activiteiten voor de (zuidelijke) Noordzee.

- Analyse van de database voor het voorkomen van kalfjes kan een indicatie geven van de gebieden die van bijzonder belang zijn voor de soort.

- Analyse van de database voor twee walvisachtigen, witsnuitdolfijn en dwergvinvis, zou nieuwe informatie over risico's voor deze soorten geven.

- Individueel gedrag binnen en rondom windparken / windmolens

Zijn er verschillen in een mogelijke reactie tussen individuele dieren, bijvoorbeeld van moeder/kalf groepen, leeftijd, reproductiestatus. Hiervoor is aanvullende kennis nodig over mogelijke verschillen in het gebruik in het windpark tussen individuen.

- $\quad$ Barrière-effect

Onderzoek naar mogelijk "barrière-effect" in relatie tot de ruimtelijke configuratie van de parken (afstanden tussen windmolens).

\subsubsection{Kennis en onderzoek voor identificeren windparkzoekgebied}

Met betrekking tot bruinvis en andere walvisachtigen zijn de volgende suggesties gegeven voor het identificeren van zoekgebieden voor windparken op zee:

- Jaarrondverspreiding bruinvissen ruimtelijke modelleren met de bestaande data sets en verder te monitoren.

Jaarrondverspreiding bruinvissen in kaart brengen (zie Tabel 6, bijvoorbeeld door ruimtelijke modellering van de nu bestaande data sets) om geschetste verspreiding te verifiëren of falsifiëren.

- Verbeteren van verspreidingskaarten met onderzoek naar habitatgebruik en verspreiding van prooidieren.

Een beter begrip van het habitatgebruik van bruinvissen kan ook bijdragen aan betere verspreidingskaarten. Daarvoor is het goed om informatie over de verspreiding van prooidieren te hebben.

\subsubsection{Conclusies}

Voor bruinvis en andere walvisachtigen kan op basis van de expert inschattingen de volgende beperkingen geconcludeerd worden:

- $\quad$ effecten in operationele fase minder goed bekend;

- doorwerking populatieniveau niet bekend;

- gedrag binnen/buiten windparken niet bekend;

- de minste effecten worden verwacht voor zoekgebied 1;

- de meeste effecten worden verwacht voor de zoekgebieden 2, 3,4 en 8

- $\quad$ voor de zoekgebieden 5, 6 en 7 zijn de potentiele effecten onduidelijk. 


\subsection{Vleermuizen}

Op basis van input van Sander Lagerveld

\subsubsection{Informatie over verspreiding en effecten}

Hieronder is aangegeven welke informatie is gebruikt voor de totstandkoming van de kaarten van de Gebiedensessie Nieuwe Windgebieden Noordzee gehouden op 4 februari 2020 en/of de aanvullende consultatie en wat de beperkingen zijn van die informatie, zoals aangegeven door de expert.

Verspreiding van vleermuizen is gebaseerd op de volgende gegevens, inclusief beperkingen daarvan:

- Informatie over het voorkomen op zee is met name gebaseerd op akoestische monitoring met batdetectors (Hatch et al., 2013; Lagerveld et al., 2019). Beperkingen zijn met name ruimtelijk, aangezien er geen gegevens zijn voor de volledige Nederlandse Noordzee. Monitoring heeft vrijwel uitsluitend plaatsgevonden in het zuidelijk deel van het NCP. Informatie is daarom beperkt tot zoekgebied 1 en 2 . Om verantwoorde uitspraken te kunnen doen over het voorkomen van vleermuizen ten noorden van de Waddeneilanden zal het batdetector-meetnet uitgebreid moeten worden (of zal op een andere manier onderzoek moeten worden gedaan, bijvoorbeeld m.b.v. telemetrie). Op dit moment is daar slechts een operationele batdetector-meetlocatie (Gemini). De meest algemene soort op zee is de ruige dwergvleermuis. Andere soorten die op de Noordzee zijn vastgesteld zijn tweekleurige vleermuis, rosse vleermuis, bosvleermuis, noordse vleermuis, laatvlieger en gewone dwergvleermuis.

- Voorkomen van vleermuizen op de Noordzee, alsmede het gedrag en potentieel slachtofferrisico offshore (Cryan \& Brown, 2007; Baerwald et al., 2008; Boshamer \& Bekker, 2008; Ahlén et al., 2009; Hatch et al., 2013; Lagerveld et al., 2014; Leopold et al., 2014; Petersen et al., 2014; Lagerveld et al., 2015; Hüppop \& Hill, 2016; Lagerveld, 2017; Buij et al., 2018; Lagerveld et al., 2019; Brabant et al., 2020; Lagerveld et al., 2020). Beperkingen daarvan zijn:

- Ruimtelijk, hoogte: Alle batdetector-data is verzameld op een hoogte van ca $25 \mathrm{~m}$ boven zeeniveau. Voor ruige dwergvleermuizen bedraagt het maximale detectiebereik ca $25 \mathrm{~m}$ en voor rosse Vleermuizen ca $75 \mathrm{~m}$. Hierdoor is er alleen monitoringsdata beschikbaar in de onderste luchtlaag. Buitenlands onderzoek laat zien dat vleermuizen $>200 \mathrm{~m}$ hoog kunnen vliegen boven zee (Hatch et al., 2013) en daarom is het waarschijnlijk dat een deel van de vleermuisactiviteit boven zee wordt gemist.

- Ruimtelijk, lengte/breedtegraad: de indruk bestaat dat de meeste migratie activiteit plaatsvindt ten westen van de Hollandse/Zeeuwse kust, en dat er minder migratie plaatsvindt ten noorden van de Waddeneilanden (maar hard bewijs ontbreekt). Naast migratie-activiteit is er in sommige gevallen ook sprake van foeragerende vleermuizen. $\mathrm{Er}$ is een zomerwaarneming van een rosse vleermuis op Europlatform (55 km van de dichtstbijzijnde kolonie), en verschillende andere dichterbij de kust (LUD, PAWP, OWEZ, Lichteiland Goeree). Tracks van GPS gezenderde Rosse vleermuizen hebben een maximale afstand van $12 \mathrm{~km}$ uit de kust opgeleverd.

- Temporeel: De meeste vleermuisactiviteit op zee vindt plaats tijdens het migratieseizoen (van eind maart tot in juni en van eind augustus tot in oktober), maar er worden dus ook soms dieren midden in de zomer vastgesteld.

Informatie over de effecten is gebaseerd op het volgende, inclusief beperkingen daarvan:

- Zoekgebied 1 en 2 overlappen met migrerende vleermuizen. Er is geen informatie over de overige zoekgebieden. In hoeverre realisatie van windparken in zoekgebied 1 en 2 populatieconsequenties kan hebben is onbekend, dat wordt momenteel onderzocht in het WOZEP-programma. Voor de andere zoekgebieden kunnen geen uitspraken worden gedaan en zal er eerst onderzoek gedaan moeten worden. Foeragerende vleermuizen afkomstig van kolonies van het vasteland betreffen net name rosse vleermuizen. Kolonies van deze soort worden (langs de kust) aangetroffen in het gebied tussen Callantsoog en Oostvoorne. Op de Wadden, langs de kust van Friesland en Groningen en in Zeeland komen rosse vleermuizen niet/nauwelijks voor. Er van uitgaande dat de maximum foerageerrange van rosse 
vleermuizen boven zee $55 \mathrm{~km}$ bedraagt dan zou zoekgebied 2 nog net bereikt kunnen worden door dieren vanuit Callantsoog.

\subsubsection{Risico's windparkzoekgebieden}

De expert is gevraagd een inschatting te maken over welke windparkzoekgebieden meer of minder geschikt zijn voor wind op zee ten aanzien van de desbetreffende soortgroep en daarbij ook aan te geven met welke zekerheid die inschatting te maken is.

De geschatte risico's van de windparkzoekgebieden voor vleermuizen zijn hieronder aangegeven, waarbij de volgende classificering is gebruikt: Laag (negatieve effecten zijn naar verwachting minimaal); Hoog (verwachte negatieve effecten); Neutraal (geen bijzonderheden / gebied is niet van specifiek belang); Onduidelijk (onvoldoende kennis om (on)geschiktheid in te schatten). Bij elke inschatting is een indicatie van de zekerheid gegeven.

- $\quad$ Risico windparkzoekgebied 1 Hoog (lage zekerheid)

Zoekgebied 1 en 2 liggen (nog net) ten westen van de Hollandse kust, en op deze locaties worden op regelmatige basis migrerende vleermuizen verwacht. In hoeverre realisatie van windparken in deze gebieden populatieconsequenties heeft is nog onduidelijk, die vraag wordt geprobeerd in het WOZEP-programma te beantwoorden. Over de andere zoekgebieden kunnen geen uitspraken worden gedaan. Daarvoor zal er eerst onderzoek gedaan moeten worden.

- $\quad$ Risico windparkzoekgebied 2 Hoog (lage zekerheid)

Zoekgebied 1 en 2 liggen (nog net) ten westen van de Hollandse kust, en op deze locaties worden op regelmatige basis migrerende vleermuizen verwacht. In hoeverre realisatie van windparken in deze gebieden populatieconsequenties heeft is nog onduidelijk, die vraag wordt geprobeerd in het WOZEP-programma te beantwoorden. Over de andere zoekgebieden kunnen geen uitspraken worden gedaan. Daarvoor zal er eerst onderzoek gedaan moeten worden. Het is niet uitgesloten dat rosse vleermuizen zoekgebied 2 kunnen bereiken tijdens foerageertrips, maar het lijkt onwaarschijnlijk dat dit op regelmatige basis plaatsvindt.

- Risico windparkzoekgebied 3 Onduidelijk

- $\quad$ Risico windparkzoekgebied 4 Onduidelijk

- $\quad$ Risico windparkzoekgebied 5 Onduidelijk

- $\quad$ Risico windparkzoekgebied 6 Onduidelijk

- $\quad$ Risico windparkzoekgebied 7 Onduidelijk

- $\quad$ Risico windparkzoekgebied 8 Onduidelijk

\subsubsection{Benodigde extra informatie}

Volgens de expert inschatting zou de volgende (type) informatie nodig zijn om een inschatting van de risico's in de toekomst goed te kunnen maken:

- Vlieghoogte

Welke vlieghoogtes worden gebruikt boven zee? (alle soorten vleermuizen) (ihkv WOZEPprogramma)

- Slachtofferrisico Wat is het slachtofferrisico van offshore windturbines? (alle soorten vleermuizen) (ihkv WOZEP-programma)

- Populatiestructuur en -omvang Populatiestructuur en omvang relevante (sub)populaties? (Ruige Dwergvleermuizen) (ihkv WOZEP-programma)

- Migratieroutes

- Welk percentage dieren migreert over zee dan wel langs de kust? (Ruige Dwergvleermuizen) (ihkv WOZEP-programma) 
- Het is zinvol om meer telemetrieonderzoek te doen naar: Voorjaarsmigratie vanuit de UK (hoeveel dieren komen binnen via de Nederlandse kust en hoeveel dieren passeren 'bovenlangs' ?)

- Het is zinvol om meer telemetrieonderzoek te doen naar: Najaarsmigratie vanuit Noord Duitsland (in kaart brengen migratieroutes van dieren die potentieel ten noorden van de Waddeneilanden passeren).

- $\quad$ Verspreiding Spatieel en temporeel voorkomen offshore, relatie met het weer? (Ruige Dwergvleermuizen) (ihkv WOZEP-programma)

- $\quad$ Gedrag in windparken Gedrag in offshore windparken (aantrekking en verblijftijd)? (Ruige Dwergvleermuizen) (ihkv WOZEP-programma)

- Foerageergedrag

Foerageergedrag offshore van lokale populaties? (Rosse vleermuizen) (ihkv WOZEPprogramma)

- Uitbreiding batdetectornetwerk om over alle zoekgebieden van informatie te beschikken Indien de geografische scope van offshore wind ontwikkeling wordt uitgebreid dan zal het batdetectornetwerk significant moeten worden uitgebreid. Onderzoek zou ook eventueel kunnen plaatsvinden middels telemetrie. In dat geval dienen een significant aantal telemetrie ontvangers offshore te worden gerealiseerd. Zenderen dient in dat geval plaats te vinden in noord Duitsland of Denemarken (tijdens najaarsmigratie) of in Norfolk (tijdens voorjaarsmigratie).

\subsubsection{Kennis en onderzoek voor identificeren windparkzoekgebied}

Met betrekking tot vleermuizen zijn de volgende suggesties gegeven voor het identificeren van zoekgebieden voor windparken op zee:

- Migratieroutes vermijden en effectieve stilstand-algoritmen voor windparken ontwikkelen. Offshore windparken dienen in principe gerealiseerd te worden buiten de migratieroutes (indien aanwezig, thans nog niet bewezen). Indien dat niet mogelijk is, dient goed te worden onderzocht wanneer en onder welke omstandigheden vleermuizen in het specifieke gebied voorkomen zodat effectieve stilstand-algoritmen kunnen worden ontwikkeld.

- Vaststellen van het slachtofferrisico, populatiestructuur/omvang en populatie-effecten door windparken.

Vaststellen van het slachtofferrisico op zee in combinatie met de populatiestructuur/omvang waarmee kan worden bepaald wat de populatie-effecten zijn. De effect-assessment kan mogelijk leiden tot een begrenzing van het totaal aantal windmolens op zee, dus ook relevante informatie bij het bepalen van de zoekgebieden.

\subsubsection{Conclusies}

Voor vleermuizen kan op basis van de expert inschattingen het volgende geconcludeerd worden:

- Kennis over de verspreiding is (zeer) beperkt: er zijn slechts voor 2 van de 8 zoekgebieden gegevens bekend.

- Voor zoekgebieden 1 en 2 zijn de potentiele effecten groot. Voor de overige gebieden zijn de potentiele effecten onduidelijk.

- Om verantwoorde uitspraken te kunnen doen over de risico's van windparkzoekgebieden is aanvullend onderzoek nodig, waarvan een deel al loopt ihkv WOZEP-programma. 


\subsection{Vissen}

Op basis van input van Ralf van $\mathrm{Hal}$

\subsubsection{Informatie over verspreiding en effecten}

Hieronder is aangegeven welke informatie is gebruikt voor de totstandkoming van de kaarten van de Gebiedensessie Nieuwe Windgebieden Noordzee gehouden op 4 februari 2020 en/of de aanvullende consultatie en wat de beperkingen zijn van die informatie, zoals aangegeven door de expert.

Verspreiding van vissen is gebaseerd op de volgende gegevens, inclusief beperkingen daarvan:

- Tijdens de workshop is er weinig tot geen aandacht voor vissen geweest. Er zijn geen soortspecifieke verspreidingsgegevens gebruikt. Voor de meeste vissoorten geldt dat zij in een groot gebied voorkomen waarbinnen veel migratie plaatsvindt. Sommige soorten vertonen seizoenmigratie, terwijl voor andere verplaatsing plaatsvindt omdat verschillende levensstadia andere gebieden gebruiken (bijv. juvenielen in ondiep water aan de kust, adulten in dieper water in het midden van de Noordzee). Daarmee is waarschijnlijk dat een individuele vis in contact komt met meerdere van de geplande windparken.

- Geen specifieke informatiebron gebruikt (geen referenties) maar soort-specifieke verspreidingspatronen kunnen aan de hand van onze monitoringprogramma's vastgesteld worden.

Informatie over de effecten is gebaseerd op het volgende, inclusief beperkingen daarvan:

- Bescherming voor visserij (van Hal et al., 2012).

- Een soort als tong verblijft maar een korte tijd in een park en gebruikt in zijn dagelijks/wekelijks verplaatsing een groter gebied dan een windpark (van Hal et al., 2012). Kabeljauw is voor langere tijd dichtbij de palen waargenomen maar alle kabeljauwen zijn uiteindelijk verdwenen uit het park. Het is onwaarschijnlijk dat de volledige levenscyclus van een soort, zelfs voor kabeljauw, zich binnen een park afspeelt. Bescherming ten opzichte van de visserij, geldt dus maar voor een beperkte periode.

- Er is beperkt kennis over de impact op vissoorten. $\mathrm{Er}$ is in een aantal studies gekeken naar de commerciële platvissen en kabeljauw als ook een beperkt aantal andere soorten. Hierin is gekeken of hun aanwezigheid anders is dan buiten het park. Ook is er enig onderzoek uitgevoerd naar de verblijfsduur van de soorten.

- De impact op andere vissoorten, en hiermee op het ecosysteem, is niet tot nauwelijks onderzocht.

- $\quad$ Elektrische velden van kabels, ook buiten de parken, zorgen mogelijk voor barrières. Mogelijk dat dit een effect heeft op elasmobranchen of op trekvis. Effecten van elektrische velden op vissen zijn veelal onbekend.

- Hardsubstraat in de "zandige" zuidelijke Noordzee kan een aanvullende habitat vormen voor sommige vissoorten (Van Hal et al., 2012; Mavraki, 2020) en daarmee positieve effecten hebben voor deze soorten.

- $\quad$ Een (tijdelijke) aantrekking door de palen (Van Hal et al., 2017). De impact hiervan kan positief, negatief of neutraal zijn (vandendriessche et al., 2013; Reubens et al., 2013; Van Hal et al., 2017). De impact van aantrekking van vissen door de palen is onduidelijk.

- Beschikbaarheid/concentratie van voedsel. Het ligt niet heel erg in de verwachting dat een windparkgebied voor de gehele levenscyclus van extra waarde is in de voedselvoorziening. Effecten op de voedselvoorziening van vissen zijn onduidelijk. 


\subsubsection{Risico's windparkzoekgebieden}

De expert is gevraagd een inschatting te geven over welke windparkzoekgebieden meer of minder geschikt zijn voor wind op zee ten aanzien van de desbetreffende soortgroep en daarbij ook aan te geven met welke zekerheid die inschatting te maken is.

De risico's van de windparkzoekgebieden voor vissen zijn allemaal neutraal ingeschat, met een lage zekerheid.

De expert heeft het volgende aangegeven: $\mathrm{Er}$ is een grote verscheidenheid aan vissoorten in deze gebieden welke anders kunnen reageren. Afhankelijk van de prioritering van de verschillende vissoorten kan de impact negatief, positief of neutraal uitvallen.

\subsubsection{Benodigde extra informatie}

Volgens de expert inschatting zou de volgende (type) informatie nodig zijn om een inschatting van de risico's in de toekomst goed te kunnen maken:

- Impact (aanwezigheid binnen versus buiten windparken, inclusief verblijfsduur) voor meer vissoorten onderzoeken en hiermee impact op het ecosysteem (voedselweb-relaties)

- $\mathrm{Er}$ is beperkt kennis over de impact op vissoorten. Enig onderzoek met telemetrie en merken is verricht naar verschillen in aanwezigheid binnen/buiten het park en verblijfsduur voor de commerciële platvissen en kabeljauw en een beperkt aantal andere soorten.

- De impact op andere vissoorten en hiermee op het ecosysteem is niet tot nauwelijks onderzocht. Het op grote schaal bouwen van de windparken heeft waarschijnlijk ook op andere soorten en via voedselweb-relaties op meerdere soorten effect.

- Effecten van aantrekking tot hard substraat en palen (duur, welke soorten, populatieeffecten). Specifiek te noemen zijn de impact van de verspreiding van hard substraat soorten en van de aantrekking van vissen door palen. De aantrekking is zichtbaar gemaakt, maar de duur is onzeker, om welke vissoorten het precies gaat is onzeker. Aantrekking is wel geconstateerd bij steenbolk, wijting, kabeljauw, makreel, horsmakreel, haring, sprot, zeebaars. Onbekend is of de aantrekking enige impact heeft op de ontwikkeling van de betreffende soort.

- Voorkomen zandspiering en overlap met windmolens Als een van de belangrijkste voedselbronnen zou er gekeken moet worden naar de overlap van zandspiering met windparkgebied. Er wordt al uitgebreider onderzoek gedaan naar de aanwezigheid van zandspiering (Aarts et al., 2020).

- Mogelijke beperking van migratieroutes door kabeltracés Er zou gekeken moeten worden naar de plaatsing van de kabels en of deze mogelijke migratieroutes beperken. Er zijn plannen voor een onderzoek aan de impact van elektrische velden (Borsele) op platvis.

\subsubsection{Conclusies}

Voor vissen kan op basis van de expert inschattingen het volgende geconcludeerd worden:

- Vissen betreft relatief diverse gemeenschap bestaand uit vele soorten en respons is afhankelijk van de soort.

- Zeer diverse groep die zonder verdere prioritering zo ongeveer overal even veel voorkomt en met een zelfde kwetsbaarheid, invloed van windparken valt weg bij aggregatie waardoor de inschatting neutraal wordt voor alle gebieden. 


\subsection{Rifbouwende soorten}

Op basis van input van Oscar Bos

\subsubsection{Informatie over verspreiding en effecten}

Hieronder is aangegeven welke informatie is gebruikt voor de totstandkoming van de kaarten van de Gebiedensessie Nieuwe Windgebieden Noordzee gehouden op 4 februari 2020 en/of de aanvullende consultatie en wat de beperkingen zijn van die informatie, zoals aangegeven door de expert.

Verspreiding van rifbouwende soorten is gebaseerd op kaarten van de actuele en potentiële verspreiding van rifvormende schelpdieren en wormen op het NCP (Bos et al., 2019). De kaarten uit Bos et al. (2019) die voor deze expert inschatting zijn gebruikt zijn hieronder in Figuur $7 \mathrm{t} / \mathrm{m}$ Figuur 10 weergegeven. Figuur 7 toont de voorspelling van de verspreiding (aantal $/ \mathrm{m}^{2}$ ) van de schelpkokerworm, Lanice conchilega op basis van de MWTL data (1991-2015), zoals beschikbaar via het Informatiehuis Marien (download september 2018). Data uit andere surveys, zoals vissurveys zijn niet meegenomen, omdat schelpkokerwormen daarin nauwelijks tot niet gevangen worden. Data zijn vierdemachtswortel getransformeerd, volgens de methode zoals beschreven in de Ecologische Atlas Noordzee (Lindeboom et al., 2008). De voorspelde kaart is gemaakt door te extrapoleren tussen monsterpunten (kriging: ordinary kriging, neighbors to include 5, at least 2), waarbij de niveau 3habitatkaart van EUNIS (zie Lindeboom et al., 2008) als begrenzing is gebruikt. Meer uitleg over deze methode is weergegeven in Lindeboom et al. (2008). Ook zijn de locaties van windparken, Natura 2000-gebieden en KRM- gebieden weergegeven. De schelpkokerworm, Lanice conchilega, vormt met zijn kokers bekleed met schelpresten en zand een soort 'hoogpolig tapijt' op de zeebodem, dat aantrekkelijk is voor andere soorten en zorgt voor een hogere biodiversiteit (Coolen et al., 2015). De kaart laat zien dat de schelpkokerworm Lanice conchilega wijdverbreid in de Noordzee voorkomt, en op verschillende locaties riffen vormt (zie kaart puntdata). We spreken van een Lanice-veld of -rif bij dichtheden van > 500 ind $/ \mathrm{m}^{2}$ (Rabaut et al., 2009). 


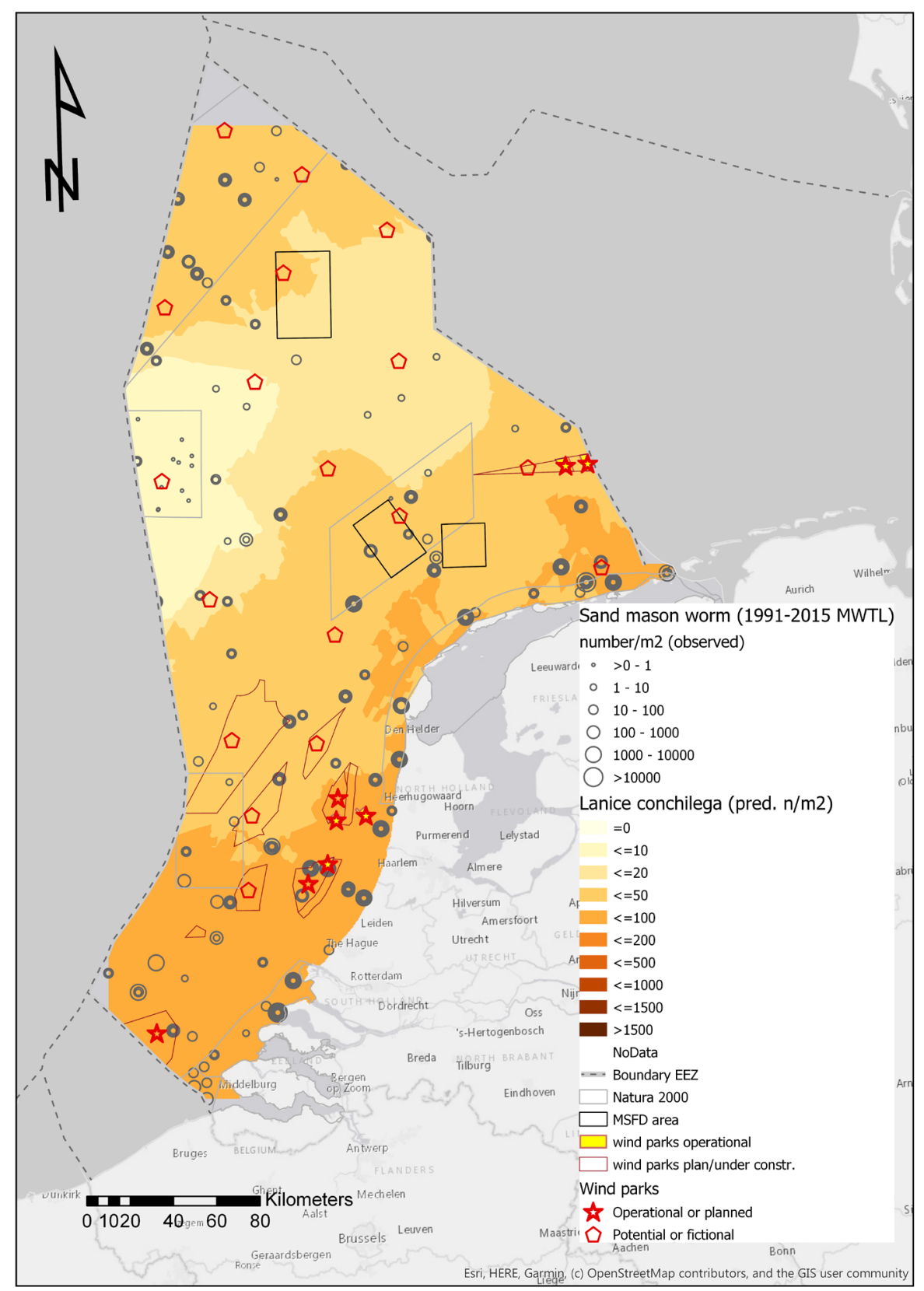

Figuur 7 Schelpkokerworm (Lanice conchilega; geschiktheid) (Bos et al., 2019). 
Figuur 8 toont de voorspelde verspreiding van gestekelde zandkokerworm (Sabellaria spinulosa) op basis van monsterdata (n/m2) verzameld door duikers op scheepswrakken (2013, 2015, 2017, 2018; ongepubliceerde gegevens), in het Prinses Amalia Windpark (Vanagt \& Faasse, 2014) en op olie- en gasplatforms (2014-2016; Coolen et al., 2018 plus ongepubliceerde data). De voorspelling is gedaan door correlatie van de gegevens met omgevingsvariabelen (afstand tot de zandbodem, suspended particulate matter en chlorofyl), met behulp van generalised additive modelling (GAM), volgens de methode beschreven in Coolen et al., (2016). J.C.= Joop Coolen. Op dezelfde locaties zijn vaak meerdere cirkels zichtbaar, omdat er op meerdere momenten of plekken bemonsterd is. Ook zijn de locaties van windparken, Natura 2000-gebieden en KRM-gebieden weergegeven.

Gezien de geringe spreiding van datapunten en het ontbreken van data dicht bij de kust, is de betrouwbaarheid van de voorspelling laag tot matig, met name in kustgebieden waar de kans hoog wordt geschat terwijl er weinig monsters zijn genomen. De kaart geeft de kans op Sabellaria spinulosa weer óp en rond de installaties direct bij de bodem. De voorspelling laat zien dat de zandkokerworm vooral op ruime afstand van de Noord-Hollandse kust voorkomt, en niet in slibrijke gebieden, zoals de diepere delen in het midden van de Nederlandse Noordzee (bv. Oestergronden).

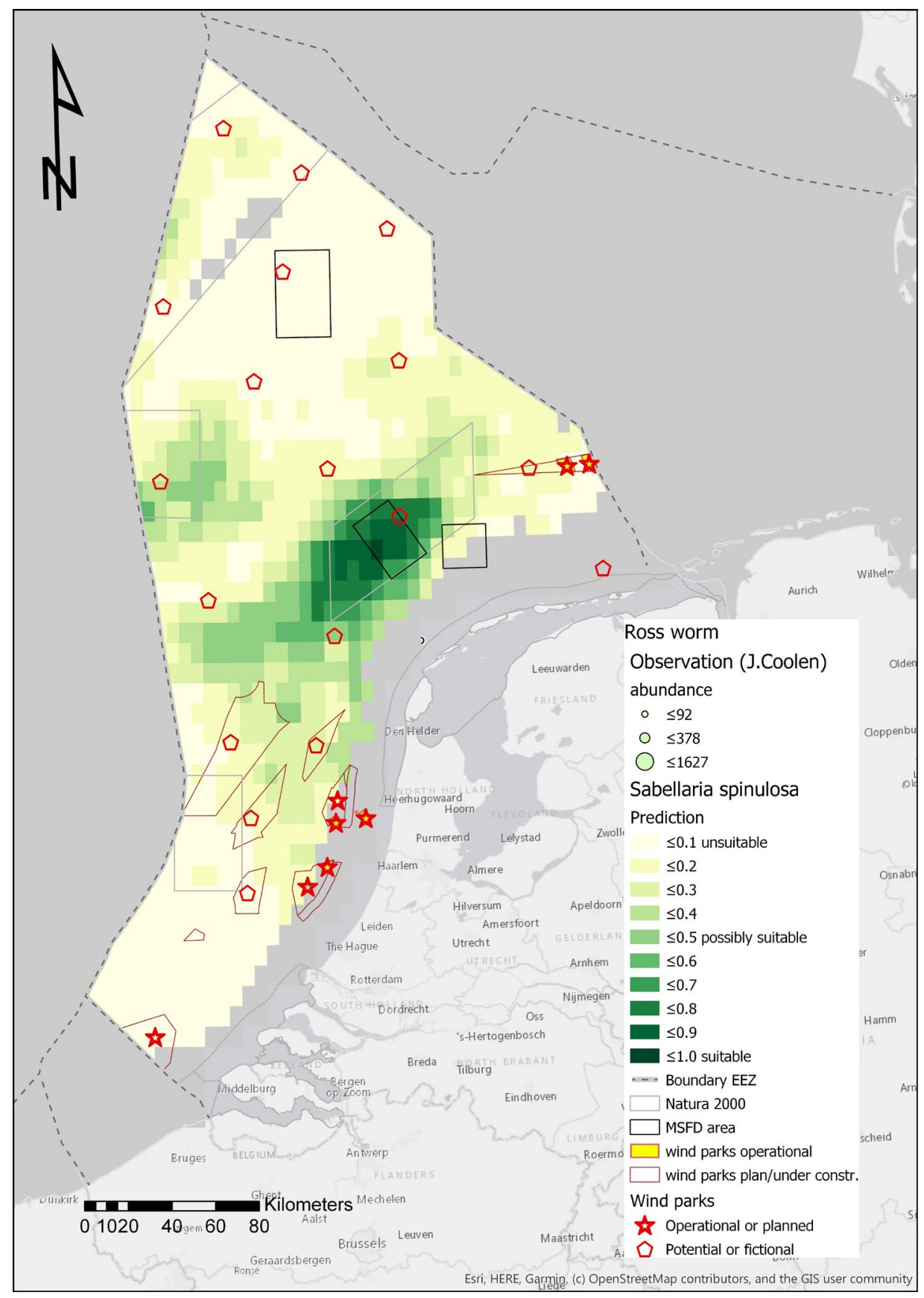

Figuur 8 Gestekelde zandkokerworm (Sabellaria spinulosa) (geschiktheid) (Bos et al., 2019). 
Figuur 9 geeft een beeld van het potentiële voorkomen van mosselen (Mytilus edulis) op verticale structuren van installaties in zee. Het gaat om een voorspelde gradiënt van het gewicht van mosselen $(\mathrm{kg} / \mathrm{m} 2)$ op harde substraten die in contact staan met het wateroppervlak, zoals boeien, windturbines en olie- en gasinstallaties. De onderliggende data zijn verzameld tijdens een gerichte bemonstering van mosselen op navigatieboeien in 2015 (Kamermans et al., 2016) en op offshoreplatforms door Coolen et al. (2018, plus ongepubliceerde data). De voorspelling is gedaan door correlatie van de gegevens met omgevingsvariabelen (Suspended Particulate Matter (SPM), chlorofyl, afstand tot de kust, en leeftijd van het onderzochte object), met behulp van Generalised Additive Modelling (GAM), volgens de methode beschreven in Coolen et al. (2016). De betrouwbaarheid van de voorspelling is hoog in de gebieden rondom de datapunten en laag in gebieden ver van de datapunten, zoals in bepaalde kustgebieden waar de kans laag wordt geschat terwijl er weinig monsters zijn genomen. Op de kaart is te zien dat de grootste dichtheden mosselen nabij het wateroppervlak worden verwacht in de zuidelijke Noordzee en boven de Waddeneilanden. Ook zijn de locaties van windparken, Natura 2000-gebieden en KRM-gebieden weergegeven.

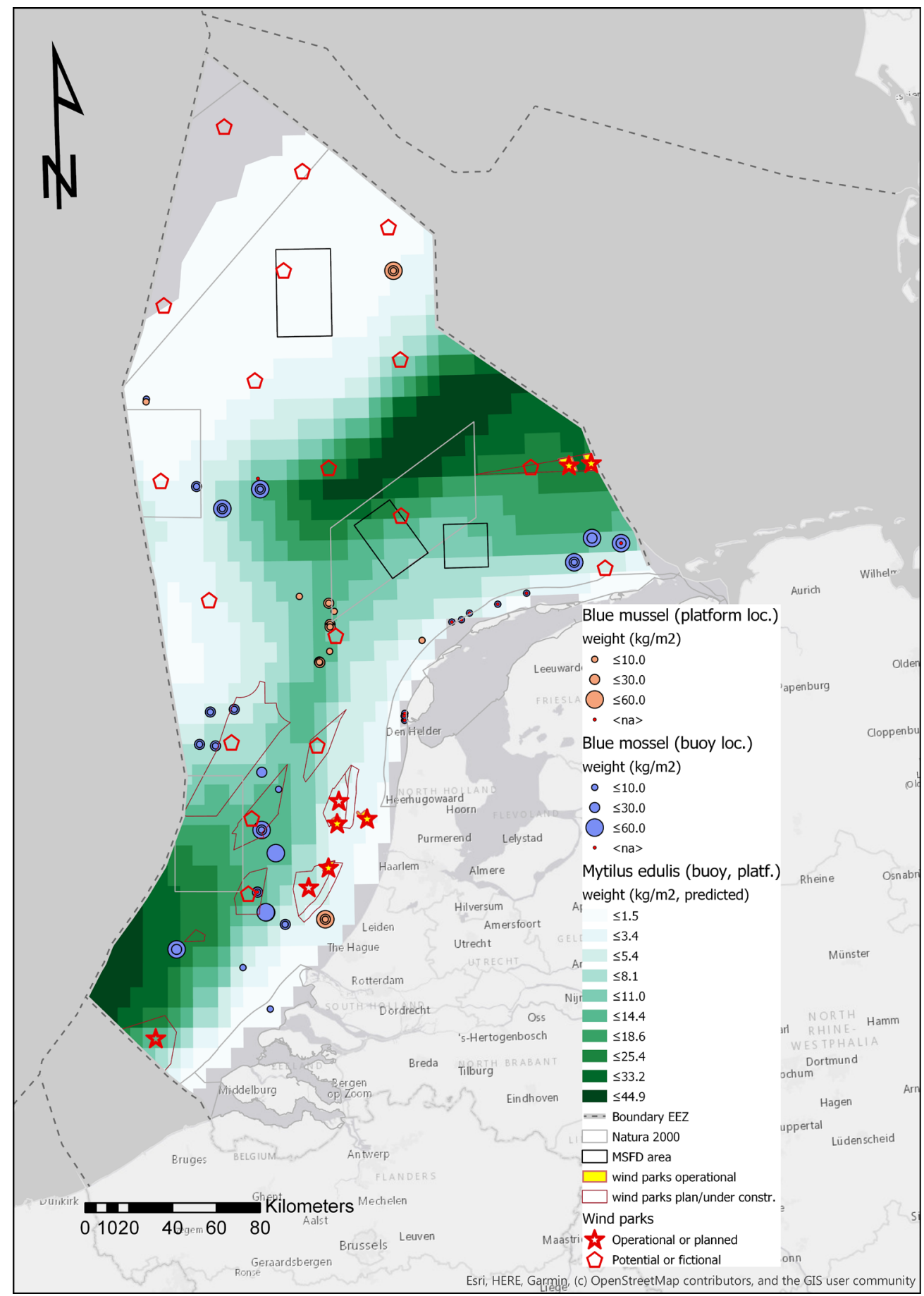

Figuur 9 Mossel (Mytilus edulis) (voorspelde gradiënt) (Bos et al., 2019). 
Figuur 10 toont de geschiktheid van bestaande, geplande windenergie-op-zee-locaties en aanvullende potentiële en fictieve windenergie-op-zee-locaties (i.e. de punten $\mathrm{CP}_{-} 4 \mathrm{t} / \mathrm{m} \mathrm{CP} \_17$ in Kamermans et al., 2018) voor herstel van de platte oester (Ostrea edulis) op basis van abiotische en biotische factoren. De offshorewindlocaties 'Borssele' en 'Buitengaats' (groene stippen) lijken binnen de bestaande en geplande wind-op-zee locaties het meest geschikt. Meer informatie is te vinden in Kamermans et al. (2018).

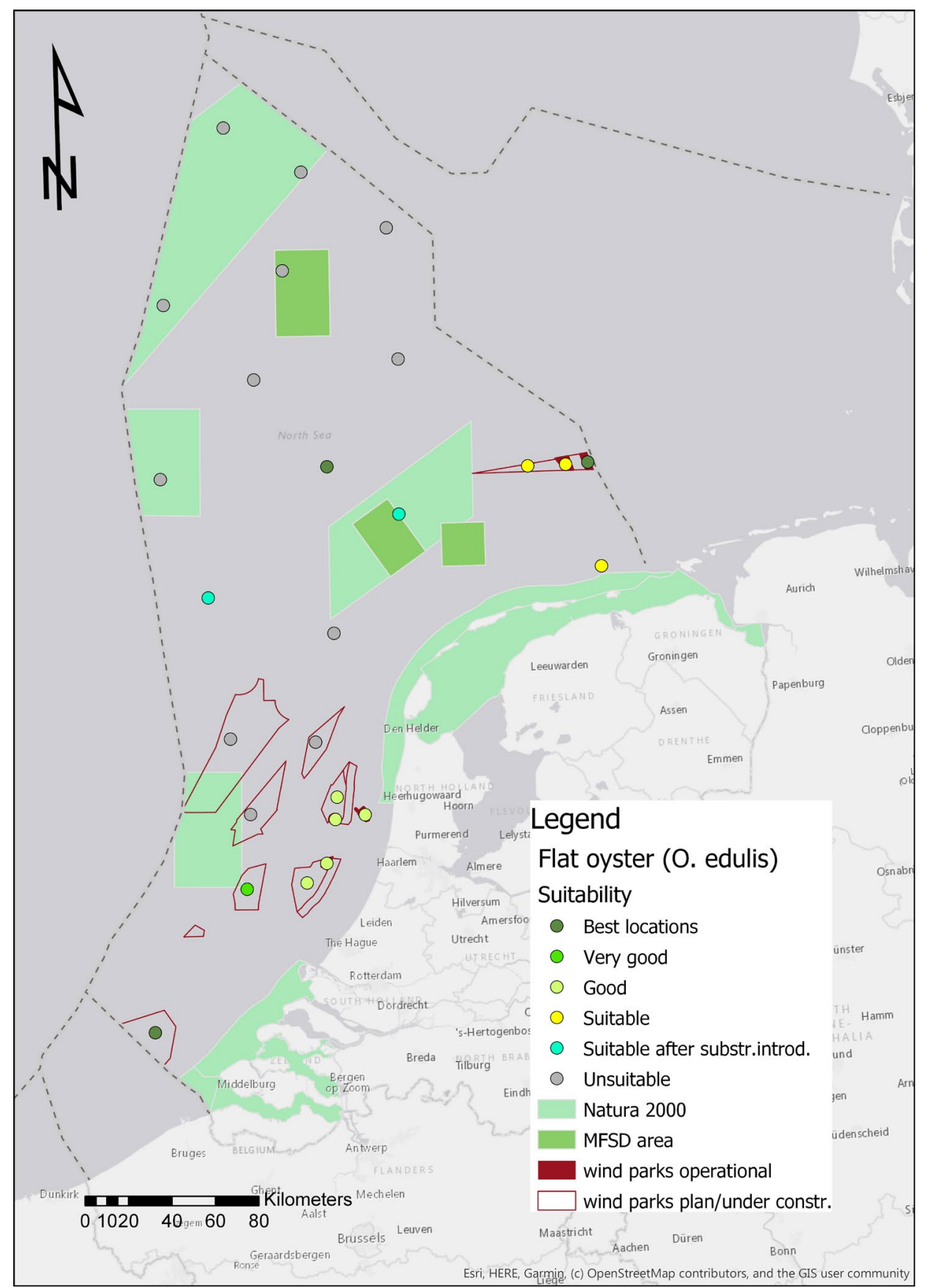

Figuur 10 Platte oester (Ostrea edulis) (geschiktheid) (Bos et al., 2019).

Er is niet ingegaan op de mogelijke (verschillende) positieve effecten op het reeds aanwezige benthos ten gevolge van de uitsluiting van bodemberoerende visserij.

Informatie over de effecten is gebaseerd op het volgende, inclusief beperkingen daarvan:

- Voor de inschatting van de zoekgebieden o.b.v. (on)geschiktheid voor rifbouwende soorten is in deze expert consulatie alleen gekeken naar de mogelijk positieve effecten/kansen op dit type organismen. Men dient zich echter te realiseren dat er nog andere benthossoorten zijn die mogelijk positief worden beïnvloed, namelijk:

- Het toevoegen van hard substraat (erosiebescherming en turbinepalen) creëert ruimte voor hard substraat minnende soorten; 
- De uitsluiting van bodemberoerende visserij is positief voor het benthos, met name voor langlevende, rifbouwende soorten en schelpdieren.

- $\quad$ r is voor deze inschatting niet gekeken naar mogelijk negatieve impact op benthos:

- Als gevolg van windmolenparken kan ter plaatse en "stroomafwaarts" de bodemsamenstelling veranderen t.g.v. een verandering in de hydrografie. Dit kan ook weer effect hebben op het bodemleven en de rest van het ecosysteem.

- De turbinepalen zorgen ook voor hard substraat hoog in de waterkolom waarop zich onder andere mosselen vestigen. Dit kan zorgen voor een sterke filtratie op fytoplankton hoog in de waterkolom dat voor verschuivingen elders kan zorgen (zoals algenbloei, voedselbeschikbaarheid voor schelpdieren en zoöplankton stroomafwaarts, etc.). Hoe groot dit effect zal zijn en waar en wanneer dit een rol gaat spelen is nog onbekend.

\subsubsection{Risico's windparkzoekgebieden}

De expert is gevraagd een inschatting te maken over welke windparkzoekgebieden meer of minder geschikt zijn voor wind op zee ten aanzien van de desbetreffende soortgroep en daarbij ook aan te geven met welke zekerheid die inschatting te maken is.

De inschatting van de geschiktheid van de windparkzoekgebieden voor rifbouwende soorten is hieronder weergegeven, waarbij is ingeschat of een windpark op de locatie een kans is voor soort(groep) / Positieve effecten verwacht). Bij elke inschatting is een indicatie van de zekerheid gegeven.

- Kans windparkzoekgebied 1

- Kans windparkzoekgebied 2

- Kans windparkzoekgebied 3

- Kans windparkzoekgebied 4 (matige zekerheid)

- $\quad$ Kans windparkzoekgebied 5 zekerheid)

- Kans windparkzoekgebied 6

- Kans windparkzoekgebied 7

- Kans windparkzoekgebied 8
Kans kokerwormen* (matige zekerheid) Kans kokerwormen, gewone mossel** (matige zekerheid) Kans kokerwormen, gewone mossel (matige zekerheid) Kans kokerwormen, gewone mossel, platte oester***

Kans Sabelaria, gewone mossel, platte oester (matige

Kans Lanice, gewone mossel, (matige zekerheid)

Kans gewone mossel (matige zekerheid)

Kans kokerwormen, platte oester (matige zekerheid)

*kokerwormen: Sabellaria spinulosa en Lanice conchilega

**Gewone mossel: Mytilus edulis

***Platte oester: Ostrea edulis

\subsubsection{Benodigde extra informatie}

Volgens de expert inschatting zou de volgende (type) informatie nodig zijn om een inschatting van de kansen in de toekomst goed te kunnen maken:

- Verspreiding en biodiversiteit

- Er wordt aan voorspellende modellen voor benthossoorten gewerkt door Joop Coolen (WMR).

- Bemonsteringen van bestaande en toekomstige windparken om te zien welke soorten ontwikkelen op welke locaties: via TKI zijn er in juni 2020 een aantal voorstellen ingediend die hiermee te maken hebben (monitoring biodiversiteit).

- Veldonderzoek zeebodemstructuren en sediment:

- Side scan sonar van de bodem;

- bodemhappen van structuren die op side scan sonar veelbelovend lijken;

- videotransecten van bodem;

○ sedimentonderzoek. 


\subsubsection{Conclusies}

Voor rifbouwende soorten kan op basis van de expert inschattingen het volgende geconcludeerd worden:

- Kansen voor ontwikkeling van biogene riffen ingeschat op basis van verspreidingskaarten rifbouwende soorten.

- Zoekgebied 4 biedt de meeste kans (potentieel geschikt voor alle (4) beschouwde rifbouwende soorten).

- Zoekgebied 7 biedt de minste kans (potentieel geschikt voor 1 rifbouwende soort, de gewone mossel), gevolgd door zoekgebied 6 (potentieel geschikt voor 2 rifbouwende soorten).

- De overige zoekgebieden 1, 2, 3, 5 en 8 bieden kans voor 3 rifbouwende soorten.

- Mogelijke impact op benthos in het algemeen ontbreekt: effecten door verandering bodemsamenstelling (op bodemleven en ecosysteem) en aangroei palen (door toename filtratie fytoplankton).

\subsection{Risico's van windparkzoekgebieden voor soortgroepen}

De experts zijn gevraagd een inschatting te maken over welke windparkzoekgebieden meer of minder effecten zullen hebben op de desbetreffende soortgroep en daarbij ook aan te geven met welke zekerheid die inschatting te maken is. Hierbij is gebruik gemaakt van categorieën (Tabel 3). In de bovenstaande paragrafen zijn per soortgroep de geschatte risico's van zoekgebieden voor windparken weergegeven. In deze paragraaf zijn de risico's samengevoegd tot éen overzicht (Tabel 4). Deze inschatting is van slechts één (of twee) experts per soortgroep, op basis van kennis en ervaring, waarbij er geen gericht onderzoek aan vooraf is gegaan.

Voor wat betreft de verschillen tussen de zoekgebieden (Tabel 4) blijkt dat het risico voor:

- Zeevogels sterk varieert per gebied (laag, neutraal, hoog);

- Zeehonden voor elk zoekgebied hoog is en enkele onduidelijk voor wat betreft de gewone zeehond;

- Bruinvis en andere walvisachtigen sterk varieert per gebied (laag, hoog, onduidelijk);

- Vleermuizen slechts voor twee zoekgebieden ingeschat kan worden (hoog), andere gebieden zijn onduidelijk;

- Vissen voor alle gebieden neutraal is ingeschat vanwege de zeer grote diversiteit van de soortgroep;

- Rifbouwende soorten bestaat uit kansen die zijn ingeschat op basis van potentiele vestiging van rifbouwende soorten. 
Tabel 5 Schatting van de risico's van de 8 zoekgebieden voor windparken per soortgroep: Laag (negatieve effecten zijn naar verwachting minimaal); Hoog (verwachte negatieve effecten); Neutraal (geen bijzonderheden / gebied is niet van specifiek belang); Onduidelijk (onvoldoende kennis om (on)geschiktheid in te schatten); Kans (windpark is kans voor soort(groep) / Positieve effecten verwacht). Bij elke inschatting is een indicatie van de zekerheid gegeven: Laag (L); Medium / matig (M); Redelijk / relatief hoog (R); niet ingeschat of niet relevant (-). Dit betreft een samenvatting; bij de inschattingen zijn soms opmerkingen gemaakt die alleen in de bovenstaande paragrafen zijn weergegeven.

\begin{tabular}{|c|c|c|c|c|c|c|c|}
\hline \multirow{2}{*}{$\begin{array}{c}\text { Gebied } \\
\text { nr. }\end{array}$} & \multirow{2}{*}{ Zeevogels } & \multicolumn{2}{|c|}{ Zeehonden } & \multirow{2}{*}{$\begin{array}{c}\text { Bruinvis en } \\
\text { andere } \\
\text { walvisachtige } \\
\text { n }\end{array}$} & \multirow{2}{*}{$\begin{array}{l}\text { Vleer- } \\
\text { muizen }\end{array}$} & \multirow[t]{2}{*}{ Vissen } & \multirow{2}{*}{$\begin{array}{l}\text { Rifbouwe } \\
\text { nde } \\
\text { soorten* }\end{array}$} \\
\hline & & Gewone & Grijze & & & & \\
\hline 1 & Laag (M) & \multicolumn{2}{|c|}{ Hoog $(R)$} & Laag (M) & Hoog (L) & Neutraal (L) & $\begin{array}{c}\text { Kans kokerw. } \\
\text { (M) }\end{array}$ \\
\hline 2 & Laag (M) & \multicolumn{2}{|c|}{ Hoog (R) } & Hoog (M) & Hoog (L) & Neutraal (L) & $\begin{array}{c}\text { Kans kokerw., } \\
\text { gewone } \\
\text { mossel }(\mathrm{M})\end{array}$ \\
\hline 3 & Hoog (R) & $\begin{array}{c}\text { Onduidelijk } \\
(-)\end{array}$ & Hoog (R) & Hoog (M) & $\begin{array}{l}\text { Neutraal } \\
\text { (L) }\end{array}$ & Neutraal (L) & $\begin{array}{c}\text { Kans kokerw., } \\
\text { gewone } \\
\text { mossel }(\mathrm{M})\end{array}$ \\
\hline 4 & Neutraal (L) & \multicolumn{2}{|c|}{ Hoog (R) } & Hoog (M) & $\begin{array}{c}\text { Onduidelijk } \\
(-)\end{array}$ & Neutraal (L) & $\begin{array}{l}\text { Kans kokerw., } \\
\text { gewone } \\
\text { mossel, platte } \\
\text { oester (M) }\end{array}$ \\
\hline 5 & Hoog (L) & \multicolumn{2}{|c|}{ Hoog (R) } & Onduidelijk (M) & $\begin{array}{c}\text { Onduidelijk } \\
(-)\end{array}$ & Neutraal (L) & $\begin{array}{c}\text { Kans } \\
\text { Sabelaria, } \\
\text { gewone } \\
\text { mossel, platte } \\
\text { oester (M) }\end{array}$ \\
\hline 6 & Laag (M) & $\begin{array}{c}\text { Onduidelijk } \\
(-)\end{array}$ & Hoog (R) & Onduidelijk (M) & $\begin{array}{l}\text { Neutraal } \\
(\mathrm{L})\end{array}$ & Neutraal (L) & $\begin{array}{c}\text { Kans Lanice, } \\
\text { gewone } \\
\text { mossel, (M) }\end{array}$ \\
\hline 7 & Hoog (L) & \begin{tabular}{|c|} 
Onduidelijk \\
$(-)$
\end{tabular} & Hoog (R) & Onduidelijk (M) & $\begin{array}{l}\text { Neutraal } \\
(L)\end{array}$ & Neutraal (L) & $\begin{array}{c}\text { Kans gewone } \\
\text { mossel (M) }\end{array}$ \\
\hline 8 & Laag (R) & \multicolumn{2}{|c|}{ Hoog (R) } & Hoog (M) & $\begin{array}{c}\text { Onduidelijk } \\
(-)\end{array}$ & Neutraal (L) & $\begin{array}{l}\text { Kans kokerw., } \\
\text { platte oester } \\
\text { (M) }\end{array}$ \\
\hline
\end{tabular}

*kokerwormen (Sabellaria spinulosa en Lanice conchilega), gewone mossel (Mytilus edulis) en platte oester (Ostrea edulis)

Aan de hand van de schattingen in Tabel 4 zijn de gebieden hieronder weergegeven op volgorde van meest geschikt naar minst geschikt:

- Voor alle soortgroepen behalve rifbouwers (uitsluitend obv potentieel negatieve impact):

- Zoekgebied 1;

- Zoekgebied 2, 6 en 8;

- Zoekgebied 4;

- Zoekgebied 5;

- Zoekgebied 3 en 7.

- Voor alle soortgroepen, inclusief kansen voor rifbouwende soorten:

- Zoekgebied 1;

- Zoekgebied 2 en 8;

- Zoekgebied 4 en 6 ;

- Zoekgebied 5 en 7;

- Zoekgebied 3. 


\section{Algemene conclusies}

Op hoofdlijnen kan het volgende geconcludeerd worden m.b.t. gevoeligheid van soortgroepen voor offshore windparken en hun ruimtelijke ligging:

- $\quad$ Er bestaat onvoldoende kennis om effecten eenduidig te kunnen kwantificeren per zoekgebied.

- $\quad$ Expert inschattingen worden gedaan op basis van:

- Verspreiding, veelal gebaseerd op verspreidingsgegevens.

Beperkingen: o.a. niet altijd up-to-date, niet compleet met betrekking tot gebied en/of periode (snapshots).

- Impact windparken op de soortgroepen.

Beperkingen: operationele fase minder goed bekend; doorwerking populatieniveau voor sommige soort(groepen) niet bekend; gedrag binnen/buiten windparken niet (goed) bekend; effecten schaalvergroting onbekend.

- Respons per soortgroep afhankelijk van de (focus op) specifieke soorten:

- Zeevogels en vissen betreffen diverse gemeenschappen bestaande uit vele soorten;

- Zeevogels: windpark gevoeligheidskaart (geïntegreerd over verschillende soorten en ruimtelijk) beschikbaar en bruikbaar;

- Vissen: zeer diverse groep, valt weg bij aggregatie waardoor de inschatting neutraal wordt voor alle gebieden.

- Trekvogels ontbreken in huidige beoordeling. In de workshop viel deze groep onder de expertise van Bureau Waardenburg.

- Biogene riffen:

- Kansen ingeschat op basis van verspreidingskaarten rifbouwende soorten.

- Mogelijke impact op benthos in het algemeen ontbreekt: effecten door verandering bodemsamenstelling (op bodemleven en ecosysteem) en aangroei palen (door toename filtratie fytoplankton).

Voor wat betreft de verschillen tussen de zoekgebieden blijkt dat:

- Vogels

- De minste effecten worden verwacht voor de zoekgebieden 1, 2, 6 en 8 .

- De meeste effecten worden verwacht voor de zoekgebieden 3, 5 en 7.

- Zeehonden

- Voor alle zoekgebieden zijn de potentiele effecten op de grijze zeehond groot.

- Voor zoekgebieden 3, 6 en 7 zijn de potentiele effecten op de gewone zeehond onduidelijk. Voor de overige gebieden zijn de potentiele effecten groot.

- Bruinvis

- De minste effecten worden verwacht voor zoekgebied 1.

- De meeste effecten worden verwacht voor de zoekgebieden 2,3 ,4 en 8 .

○ Voor de zoekgebieden 5, 6 en 7 zijn de potentiele effecten onduidelijk.

- Vleermuizen

○ Voor zoekgebieden 1 en 2 zijn de potentiele effecten groot. Voor de overige gebieden zijn de potentiele effecten onduidelijk.

- Vissen

- Geen verschil tussen de zoekgebieden aan te geven vanwege de grote verscheidenheid aan vissoorten

- Rifbouwende soorten

- Zoekgebied 4 biedt de meeste kans (potentieel geschikt voor alle (4) beschouwde rifbouwende soorten).

- Zoekgebied 7 biedt de minste kans (potentieel geschikt voor 1 rifbouwende soort, de gewone mossel), gevolgd door zoekgebied 6 (potentieel geschikt voor 2 rifbouwende soorten).

- De overige zoekgebieden 1, 2, 3, 5 en 8 bieden kans voor 3 rifbouwende soorten. 
- Aan de hand van de expert schattingen voor alle soortgroepen tezamen, inclusief kansen voor rifbouwende soorten, is de rangorde op volgorde van afnemende geschiktheid als volgt:

- Zoekgebied 1;

- Zoekgebied 2 en 8;

- Zoekgebied 4 en 6;

- Zoekgebied 5 en 7 ;

- Zoekgebied 3. 


\section{Kwaliteitsborging}

Wageningen Marine Research beschikt over een ISO 9001:2015 gecertificeerd kwaliteitsmanagementsysteem. Dit certificaat is geldig tot 15 december 2021. De organisatie is gecertificeerd sinds 27 februari 2001. De certificering is uitgevoerd door DNV GL. 


\section{Literatuur}

Aarts et al. 2020. Zandspiering onderzoek in het kader van de Topsector Blauwe Route. https://www.nioz.nl/en/news/zandspiering-onbekend-maakt-onbemind

Aarts, G., Brasseur, S., Kirkwood, R. 2018. Behavioural response of grey seals to pile-driving, C006/18 Wageningen Marine Research, Den Helder.

Aarts, G., Brasseur, S., Poos, J.J., Schop, J., Kirkwood, R., van Kooten, T., Mul, E., Reijnders, P., Rijnsdorp, A.D., Tulp, I. 2019. Top-down pressure on a coastal ecosystem by harbor seals. Ecosphere 10, e02538.

Aarts, G., J. Cremer, R. Kirkwood, J.T. van der Wal, J. Matthiopoulos1 \& S. Brasseur, 2016. Spatial distribution and habitat preference of harbour seals (Phoca vitulina) in the Dutch North Sea. Wageningen University \& Research centre, Wageningen Marine Research, Report number C118/16, http://dx.doi.org/10.18174/400306

Ahlén I. , Baagøe H.J. \& Bach L. 2009. Behaviour of Scandinavian bats during migration and foraging at sea. Journal of Mammalogy 90: 1318-1323.

Baerwald, E.F., D'Amours G.H., Klug B.J., Barclay R.M.R. 2008. Barotrauma is a significant cause of bat fatalities at wind turbines. Current Biology 18: 695-696.

Benjamins, S., N. van Geel, G. Hastie, J. Elliott, B. Wilson, 2017.Harbour porpoise distribution can vary at small spatiotemporal scales in energetic habitats. Deep-Sea Res. II, 141 (2017), pp. 191202, https://www.sciencedirect.com/science/article/pii/S0967064516301849

Bos, O.G., Coolen, J.W.P., van der Wal, J.T. 2019. Biogene riffen in de Noordzee. Actuele en potentiële verspreiding van rifvormende schelpdieren en wormen Wageningen University \& Research rapport C058/19 (https://doi.org/10.18174/494566).

Boshamer J.P.C. \& Bekker J.P. 2008. Nathusius' pipistrelles (Pipistrellus nathusii) and other species of bats on offshore platforms in the Dutch sector of the North Sea. Lutra 51: 17-36.

Brabant, Robin \& Laurent, Yves \& Poerink, Bob \& Degraer, Steven. 2020. Activity and Behaviour of Nathusius' Pipistrelle Pipistrellus nathusii at Low and High Altitude in a North Sea Offshore Wind Farm. Acta Chiropterologica. 21. 341-348. 10.3161/15081109ACC2019.21.2.009.

Brandt M.J., Dragon A.-C., Diederichs A., Schubert A., Kosarev V., Nehls G., Wahl V., Michalik A., Braasch A., Hinz C., Ketzer C., Todeskino D., Gauger M., Laczny M. \& Piper W. 2016. Effects of offshore pile driving on harbour porpoise abundance in the German Bight- assessment of noise effects. Final report. IBL, IFAÖ \& BioConsult.

Buij, R., Jongbloed, R., Geelhoed, S., van der Jeugd, H., Klop, E., Lagerveld, S., Limpens, H., Meeuwsen, H., Ottburg, F., Schippers, P., Tamis, J., Verboom, J., van der Wal, J. T., Wegman, R., Winter, E. \& Schotman, A. 2018. Kwetsbare soorten voor energie-infrastructuur in Nederland: overzicht van effecten van hernieuwbare energie-infrastructuur en hoogspanningslijnen op de kwetsbare soorten vogels, vleermuizen, zeezoogdieren en vissen, en oplossingsrichtingen voor een natuurinclusieve energietransitie. Wageningen: Wageningen Environmental Research. 231 p. (Wageningen Environmental Research rapport; no. 2883).

Coolen J.W.P., Bos O.G., Glorius S., Lengkeek W., Cuperus J., Van der Weide B., Aguera A. 2015. Reefs, sand and reef-like sand: A comparison of the benthic biodiversity of habitats in the Dutch Borkum Reef Grounds (http://dx.doi.org/10.1016/j.seares.2015.06.010). J Sea Res 103:84-92.

Coolen J.W.P., Lengkeek W., Degraer S., Kerckhof F., Kirkwood R.J., Lindeboom H.J. 2016. Distribution of the invasive Caprella mutica Schurin, 1935 and native Caprella linearis (Linnaeus, 1767) on artificial hard substrates in the North Sea: Separation by habitat. Aquatic Invasions 11:437-449 (http://edepot.wur.nl/393771).

Coolen J.W.P., Van Der Weide B., Cuperus J., Blomberg M., Van Moorsel G.W.N.M., Faasse M.A., Bos O.G., Degraer S., Lindeboom H.J. 2018. Benthic biodiversity on old platforms, young wind farms, and rocky reefs. ICES Journal of Marine Science (https://doi.org/10.1093/icesjms/fsy092).

Cremer, J., Brasseur, S., Czeck, R., Galatius, A., Jensen, L.F., Armin, J., Körber, P., Pund, R., Siebert, U., Teilmann, J., Klöpper, S. 2019. EG-Seals grey seal surveys in the Wadden Sea and Helgoland in 2018-2019. Steadily growing, CWSS, Willemshaven. 
Cryan, P.M. \& Brown A.C. 2007. Migration of bats past a remote island offers clues toward the problem of bat fatalities at wind turbines. Biological Conservation 139: 1-11.

Galatius, A., Brasseur, S., Czeck, R., Jensen, L.F., Armin, J., Körber, P., Pund, R., Siebert, U., Teilmann, J., Klöpper, S. 2019. Trilateral surveys of Harbour Seals in the Wadden Sea and Helgoland in 2019, CWSS, Willemshaven.

Geelhoed S.C.V. \& Scheidat M. 2018. Abundance of harbour porpoises (Phocoena phocoena) on the Dutch Continental Shelf, aerial surveys 2012-2017. Lutra 61(1): 127-136.

Geelhoed S.C.V., Scheidat M., van Bemmelen R.S.A. \& Aarts G. 2013. Abundance of harbour porpoises (Phocoena phocoena) on the Dutch Continental Shelf, aerial surveys in July 2010-March 2011. Lutra 56(1): 45-57.

Gilles A., Viquerat S., Becker E.A., Forney K.A., Geelhoed S.C.V., Haelters J., Nabe-Nielsen J., Scheidat M., Siebert U., Sveegaard S., van Beest F.M., van Bemmelen R. \& Aarts G. 2016. Seasonal habitat-based density models for a marine top predator, the harbor porpoise, in a dynamic environment. Ecosphere7 (6):e01367. 10.1002/ecs2.1367

Hammond P.S., Macleod K., Berggren P., Borchers D.L., Burt M.L., Cañadas A., Desportes G., Donovan G.P., Gilles A., Gillespie D., Gordon J., Hedley S., Hiby L., Kuklik I., Leaper R., Lehnert K., Leopold M., Lovell P., Øien N., Paxton C., Ridoux V., Rogan E., Samarra F., Scheidat M., Sequeira M., Siebert U., Skov H., Swift R., Tasker M.L., Teilmann J., Van Canneyt O. \& Vázquez J.A. 2013. Cetacean abundance and distribution in European Atlantic shelf waters to inform conservation and management. Biological Conservation, 164: 107-122.

Hatch, S.K., Connelly E.E., Divoll T.J., Stenhouse I.J. \& Williams K.A. 2013. Offshore observations of Eastern red bats (Lasiurus borealis) in the Mid-Atlantic United States using multiple survey methods. PLoSOne 8 (12): e83803.

Hüppop O. \& Hill R. 2016. Migration phenology and behaviour of bats at a research platform in the south-eastern North Sea/ Lutra 59 (1-2): 5-22.

ICES. 2010. Report of the Working Group on Marine Mammal Ecology (WGMME), 12-15 April 2010, Horta, The Azores. ICES CM 2010/ACOM:24. 212 pp.

ICES. 2020. Working Group on Marine Mammal Ecology (WGMME). ICES Scientific Reports. 2:39. 85 pp. http://doi.org/10.17895/ices.pub.5975

Kamermans P., Van Duren L., Kleissen F. 2018. European flat oysters on offshore wind farms: additional locations : opportunities for the development of European flat oyster (Ostrea edulis) populations on planned wind farms and additional locations in the Dutch section of the North Sea. Wageningen Marine Research/Deltares. Report C053/18 (http://dx.doi.org/10.18174/456358). Wageningen.

Kamermans, P., Soma, K., \& Van den Burg, S. 2016. Haalbaarheid mosselteelt binnen offshorewindparken in de Nederlandse kustzone. Wageningen Marine Research rapport C075/16, Yerseke, 48p (http://edepot.wur.nl/388889).

Lagerveld, S., Gerla, D., van der Wal, J.T., de Vries, P., Brabant, R., Stienen, E., Deneudt, K., Manshanden, J. \& Scholl, M. 2017. Spatial and temporal occurrence of bats in the southern North Sea area. Den Helder: Wageningen Marine Research. 52 p. (Wageningen Marine Research report; no. C090/17).

Lagerveld, S., Jonge Poerink, B. \& de Vries, P. 2015, Monitoring bat activity at the Dutch EEZ in 2014. Den Helder: IMARES. 33 p. (Report / IMARES Wageningen UR; no. C094/15).

Lagerveld, S., Jonge Poerink, B., Haselager, R. \& Verdaat, J.P. 2014. Bats in Dutch offshore wind farms in autumn 2012. Lutra. 57, 2, p. 61-69.

Lagerveld, S., Noort, C.A., Meesters, L., Bach, L., Bach, P. \& Geelhoed, S. 2020. Assessing fatality risk of bats at offshore wind turbines. Den Helder: Wageningen Marine Research. 39 p. (Wageningen Marine Research rapport; no. C025/20).

Lagerveld, S., van der Wal, J.T., Vries, V., Verdaat, H., Sonneveld, C., van der Meer, J., Brabant, R. \& Noort, B. 2019. Bats at the southern North Sea in 2017 \& 2018. Den Helder: Wageningen Marine Research. 36 p. (Wageningen Marine Research report ; C062/19).

Laia Rojano-Doñate, Birgitte I. McDonald, Danuta M. Wisniewska, Mark Johnson, Jonas Teilmann, Magnus Wahlberg, Jakob Højer-Kristensen, Peter T. Madsen, 2018. High field metabolic rates of wild harbour porpoises. Journal of Experimental Biology 2018 221: jeb185827 doi: 10.1242/jeb.185827 Published 6 December 2018

Leopold, M.F., Boonman, M., Collier, M.P., Davaasuren, N., Jongbloed, R.H., Lagerveld, S., van der Wal, J.T. \& Scholl, M.M. 2014. A first approach to deal with cumulative effects on birds and bats of 
offshore wind farms and other human activities in the southern North Sea. Den Burg: IMARES. 188 p. (Report / IMARES Wageningen UR; no. C166/14).

Lindeboom H.J., Dijkman E.M., Bos O.G., Meesters E.H., Cremer J.S.M., De Raad I., Van Hal R., Bosma A. 2008. Ecologische Atlas Noordzee ten behoeve van gebiedsbescherming. Wageningen IMARES (http://edepot.wur.nl/251730).

Mavraki, O. 2020. On the food-web ecology of offshore wind farms, the kingdom of suspension feeders. Proefschrift. Universiteit Gent.

Petersen A., Jensen J.K., Jenkins P., Bloch D. \& Ingimarsson F. 2014. A review of the occurrence of bats (Chiroptera) on islands in the North East Atlantic and on North Sea installations. Acta Cropterologica 16: 169-195.

Rabaut M., Vincx M., Degraer S. 2009. Do Lanice conchilega (sandmason) aggregations classify as reefs? Quantifying habitat modifying effects. Helgoland Marine Research 63:37-46. Wageningen.

Reubens, J.T., Vandendriessche, S., Zenner, A.N., Degraer, S., \& Vincx, M. 2013. Offshore wind farms as productive sites or ecological traps for gadoid fishes?-Impact on growth, condition index and diet composition. Marine environmental research, 90, 66-74.

Roebeling, P.C., W.J. Strietman, R.H. Jongbloed, J.E. Tamis, K. Hamon, A. Eweg, S. van den Burg \& S. Reinhard (in voorbereiding). De economische en ecologische effecten van inrichtingsvarianten voor de Noordzee tot 2040-2050. Wageningen, Wageningen Economic Research \& Wageningen Marine Research, Conceptrapport augustus 2020.

Russell, D.J.F., Brasseur, S.M.J.M., Thompson, D., Hastie, G.D., Janik, V.M., Aarts, G., McClintock, B.T., Matthiopoulos, J., Moss, S.E.W., McConnell, B. 2014. Marine mammals trace anthropogenic structures at sea. Current Biology 24, R638-R639.

Scheidat M., Tougaard J., Brasseur S., Carstensen J., Polanen Petel T. van, Teilmann J. \& Reijnders P. 2011. Harbour porpoises (Phocoena phocoena) and wind farms: a case study in the Dutch North Sea. Environ Res Lett 6: 1-10.

Vanagt T., Faasse M. 2014 Development of hard substratum fauna in the Princess Amalia Wind Farm: Monitoring six years after construction. eCOAST report 2013009 (www.ecoast.be/content/documents/2013009_PAWP_hardsub_rapport_final_april_2014.pdf).

van Hal, R., A.B. Griffioen \& O.A. van Keeken 2017. Changes in fish communities on a small spatial scale, an effect of increased habitat complexity by an offshore wind farm. Marine Environmental Research 126: 26-36.

van Hal, R., A.S. Couperus, S.M.M. Fassler, S. Gastauer, B. Griffioen, N.T. Hintzen, L.R. Teal, O.A. van Keeken \& H.V. Winter 2012. Monitoring- and Evaluation Program Near Shore Wind farm (MEPNSW): Fish community IJmuiden : IMARES, (Report / IMARES C059/12) - p. 161.

Vandendriessche, S., Reubens, J., Derweduwen, J., Degraer, S., \& Vincx, M. 2013. Offshore wind farms as productive sites for fishes. Degraer, S., Brabant, R., \& Rumes, B. 2013. Environmental Impacts of Offshore Wind Farms in the Belgian Part of the North Sea: Learning From the Past to Optimise Future Monitoring Programs. Royal Belgian Institute of Natural Sciences, Brussels, 153-161.

von Benda-Beckmann, S., Geelhoed, S.C.V., Kinneging, N., van Kuijk, B., Scheidat, M., \& Versteeg, S. 2020. Assessment methodology for impulse noise: A case study on three species in the North Sea. Arcadis. https://edepot.wur.nl/531594

www.informatiehuismarien.nl/open-data 


\section{Verantwoording}

Rapport C097/20

Projectnummer: 4318100314

Dit rapport is met grote zorgvuldigheid tot stand gekomen. De wetenschappelijke kwaliteit is intern getoetst door een collega-onderzoeker en het verantwoordelijk lid van het managementteam van Wageningen Marine Research

Akkoord:

Gerjan Piet

Senior onderzoeker

Handtekening:

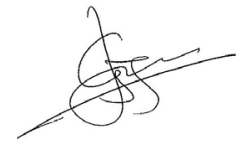

Datum:

30 oktober 2020

Akkoord:

Jakob Asjes

MT lid

Handtekening:

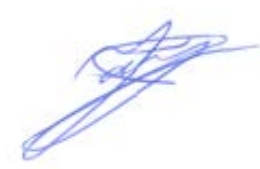

Datum:

30 oktober 2020 


\section{Bijlage I. Vragen aan experts van WMR over nieuwe windparkzoekgebieden op het NCP}

\section{Achtergrond en doel}

LNV en RWS hebben behoefte aan ruimtelijke inschatting van ecologische effecten door windparken om de discussie rondom de windparkzoekgebieden te voeden. Een belangrijke vraag hierbij is: welke zoekgebieden brengen de minste schade toe aan natuur \& biodiversiteit wanneer daar windparken zouden komen? LNV en RWS hebben deze kennis nodig voor de volgende webinar met stakeholders op 10 juni a.s.. Op deze korte termijn is het niet mogelijk om een kwantitatieve afweging te maken. Voor veel soorten/soortgroepen is de kennis op het moment beperkt tot verspreiding i.r.t. windparken en directe effecten op soorten. De doorwerking van de effecten op populatieniveau en van grootschalige uitbreiding windparken is iets wat voor veel soorten nog verder moet worden uitgewerkt, waarbij ook rekening moet worden gehouden met cumulatieve effecten door de gecombineerde invloed van menselijke activiteiten op de Noordzee. Voor de nadere invulling van de zoekgebieden en voor de discussies in de verdere toekomst over nieuwe zoekgebieden is advies nodig vanuit WMR om te investeren in dit onderzoek.

De bovengenoemde workshop is waardevol bevonden, maar LNV en RWS willen nu graag meer specifieke achtergrondinformatie (zeer korte handleiding over de argumenten en aanduiding van de beschikbare soorten-verspreidingskaarten) hebben over de gedane inschatting voor die kaarten, waarbij men aanvullend zou willen weten in welke mate er ook in ruimtelijke zin verder valt te differentiëren. M.a.w. is er tussen de 8 windparkzoekgebieden en -gebiedjes op het NCP ook een verschil in de waarde voor soorten/soortgroepen en is daaraan gekoppeld ook de mate van geschiktheid/ongeschiktheid van de 8 windparkzoekgebieden aan te geven? Men wil dus graag weten wat er wel mogelijk is en wat er niet mogelijk is. In dat laatste geval kunnen jullie de hiaten in kennis en het type benodigde onderzoek formuleren. Jullie worden daarom als experts gevraagd jullie inschatting en mening te geven.

Hieronder de WMR-experts met hun expertisegebied, die nu worden benaderd.

WMR experts

Soorten/soortgroepen

\begin{tabular}{|l|c|}
\hline Mardik Leopold & Zeevogels \\
\hline Sophie Brasseur & Zeehonden \\
\hline Steve Geelhoed en Meike Scheidat & Bruinvis \\
\hline Sander Lagerveld & Vleermuizen \\
\hline Ralf van Hal & Vissen \\
\hline Oscar Bos & Benthos (m.n. rifbouwende soorten) \\
\hline
\end{tabular}

In onderstaande tabel staan de 8 windparkzoekgebieden, die ook op de bijgevoegde kaart (pdf) staan. LNV en RWS pogen uit deze 8 dan ca. 4 gebieden te kiezen met een gezamenlijke oppervlakte van 3000-4000 km² aan nieuw windparkzoekgebied. 


\begin{tabular}{|c|c|c|c|}
\hline 1 & Op de grens met Norfolk Boreas & 900 & 9 \\
\hline 2 & Ten noorden van IJmuiden-ver & 1000 & 10 \\
\hline 3 & $\begin{array}{l}\text { Ten noordwest van IJmuiden ver, tussen de twee } \\
\text { scheepvaartroutes in }\end{array}$ & 300 & 3 \\
\hline 4 & Defensie oefengebied ten noorden van de Wadden & 1300 & 13 \\
\hline 5 & $\begin{array}{l}\text { Driehoek op grens met Duitsland, ten oosten van } \\
\text { nieuwe scheepvaart passage }\end{array}$ & 600 & 6 \\
\hline 6 & $\begin{array}{l}\text { Gebied ten noorden van Friese Front, ten westen } \\
\text { van nieuwe scheepvaart passage }\end{array}$ & 2000 & 20 \\
\hline 7 & Ten oosten van Klaverbank & 1000 & 10 \\
\hline 8 & Ten noordwesten van Texel & 150 & 1,5 \\
\hline
\end{tabular}

Graag ontvangen wij de door jullie schriftelijke reacties uiterlijk woensdag 3 juni om 12.00 uur. Voor vragen kunnen jullie je wenden naar de contactpersonen: Josien Steenbergen en Ruud Jongbloed

\section{Antwoordformulier}

\section{Naam expert:}

\section{Soorten/soortgroepen:}

Vraag 1) Welke type informatie (verspreiding, gevoeligheid, met bronnen indien beschikbaar) over invloed van windparken voor de soorten/soortgroepen is gebruikt voor de inschatting en de totstandkoming van de kaarten van de Gebiedensessie Nieuwe Windgebieden Noordzee gehouden op 4 februari 2020 ? Geef ook aan wat de beperkingen zijn van deze kennis.

Antwoord:

Vraag 2) Geef op basis van de bestaande bovengenoemde informatie jouw beoordeling (expert judgement) over welke windparkzoekgebieden meer of minder geschikt zijn voor wind op zee ten aanzien van de desbetreffende soort/soortgroep/ecosysteem en geef daarbij ook aan hoe zeker (Laag/Medium/Groot) je hiervan bent. Gebruik hierbij de volgende indeling:

\begin{tabular}{|l|l|l|}
\hline Categorie & Risico & Omschrijving \\
\hline 1) Geschikt & Laag & Verwachte negatieve effecten zijn minimaal \\
\hline 2) Minder geschikt & Hoog & Verwachte negatieve effecten verwacht \\
\hline 3) Neutraal & Medium & $\begin{array}{l}\text { Geen bijzonderheden (gebied is niet van specifiek } \\
\text { belang) }\end{array}$ \\
\hline $\begin{array}{l}\text { 4) Windpark is kans voor } \\
\text { soort/soortgroep }\end{array}$ & Laag & Verwachte positieve effecten verwacht \\
\hline 5) Onduidelijk (te weinig kennis) & Onbekend & Onvoldoende kennis \\
\hline
\end{tabular}


Antwoord:

\begin{tabular}{|c|l|l|l|}
\hline \hline Zoekgebied nr. & (on)geschiktheid voor windparken & Zekerheid & Opmerkingen \\
\hline 1 & & & \\
\hline 2 & & & \\
\hline 3 & & & \\
\hline 4 & & & \\
\hline 5 & & & \\
\hline 6 & & & \\
\hline 7 & & & \\
\hline 8 & & & \\
\hline
\end{tabular}

Vraag 3) Indien er te weinig kennis is, kun je dan kort beschrijven wat voor (type) informatie er nodig is om die inschatting in de toekomst wel goed te kunnen maken? Dit is een kans om kort te schetsen welke kennis in welke volgorde moet worden gegenereerd.

\section{Antwoord:}

Vraag 4) De volgende fase in dit proces is dat binnen de (vastgestelde) zoekgebieden moet worden gekeken waar precies de windmolens moeten komen te staan. Wat moet er voor jouw soort/soortgroep aanvullend voor onderzoek worden gedaan om dit goed (kwantitatief) te kunnen doen?

Antwoord:

Vraag 5) Wordt het hierboven (onder 3 en 4) bedoelde onderzoek momenteel uitgevoerd of zijn daar plannen voor? Zo ja, dan graag vermelden.

Antwoord:

Vraag 6) Heb je suggesties voor het identificeren van zoekgebieden voor windparken op zee?

Antwoord: 
Wageningen Marine Research

T: $+31(0) 317480900$

E: marine-research@wur.nl

www.wur.nl/marine-research

Bezoekers adres:

- Ankerpark 271781 AG Den Helder

- Korringaweg 7, 4401 NT Yerseke

- Haringkade 1, 1976 CP IJmuiden
Wageningen Marine Research levert met kennis, onafhankelijk wetenschappelijk onderzoek en advies een wezenlijke bijdrage aan een duurzamer, zorgvuldiger beheer, gebruik en bescherming van de natuurlijke rijkdommen in zee-, kust- en zoetwatergebieden.
Wageningen Marine Research is onderdeel van Wageningen University \& Research. Wageningen University \& Research is het samenwerkingsverband tussen Wageningen University en Stichting Wageningen Research en heeft als missie: 'To explore the potential of nature to improve the quality of life' 